\title{
Effects of prepartum dietary cation-anion difference and source of vitamin $D$ in dairy cows: Vitamin D, mineral, and bone metabolism
}

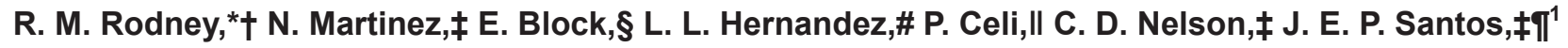 \\ and I. J. Lean*† \\ *Faculty of Veterinary Science, The University of Sydney, Camden, NSW 2570, Australia \\ †Scibus, Camden, NSW 2570, Australia \\ łDepartment of Animal Sciences, University of Florida, Gainesville 32611 \\ §Arm \& Hammer Animal Nutrition, Princeton, NJ 08543 \\ \#Department of Dairy Science, University of Wisconsin, Madison 53706 \\ IIDSM Nutritional Products, Animal Nutrition and Health, Columbia, MD 21044 \\ ID. H. Barron Reproductive and Perinatal Biology Research Program, University of Florida, Gainesville 32611
}

\begin{abstract}
Pregnant Holstein cows, 28 nulliparous and 51 parous, were blocked by parity and milk yield and randomly allocated to receive diets that differed in dietary cation-anion difference (DCAD), +130 or $-130 \mathrm{mEq} /$ $\mathrm{kg}$, and supplemented with either calcidiol or cholecalciferol at $3 \mathrm{mg} / 11 \mathrm{~kg}$ of dry matter from $255 \mathrm{~d}$ of gestation until parturition. Blood was sampled thrice weekly prepartum, and on d $0,1,2,3,6,9,12,15,18,21,24$, 27 , and 30 postpartum to evaluate effects of the diets on vitamin $\mathrm{D}$, mineral and bone metabolism, and acidbase status. Blood $\mathrm{pH}$ and concentrations of minerals, vitamin $\mathrm{D}$ metabolites, and bone-related hormones were determined, as were mineral concentrations and losses in urine and colostrum. Supplementing with calcidiol increased plasma concentrations of 25-hydroxyvitamin $\mathrm{D}_{3}$, 3-epi 25-hydroxyvitamin $\mathrm{D}_{3}, 25$-hydroxyvitamin $\mathrm{D}_{2}$, 1,25-dihydroxyvitamin $\mathrm{D}_{3}$, and 24,25-dihydroxyvitamin $\mathrm{D}_{3}$ compared with supplementing with cholecalciferol. Cows fed the diet with negative DCAD had lesser concentrations of vitamin D metabolites before and after calving than cows fed the diet with positive DCAD, except for 25 -hydroxyvitamin $\mathrm{D}_{2}$. Feeding the diet with negative DCAD induced a compensated metabolic acidosis that attenuated the decline in blood ionized $\mathrm{Ca}(\mathrm{iCa})$ and serum total $\mathrm{Ca}(\mathrm{tCa})$ around calving, particularly in parous cows, whereas cows fed the diet with positive DCAD and supplemented with calcidiol had the greatest 1,25-dihydroxyvitamin $\mathrm{D}_{3}$ concentrations and the lowest $\mathrm{iCa}$ and tCa concentrations on $\mathrm{d}$ 1 and 2 postpartum. The acidogenic diet or calcidiol markedly increased urinary losses of $\mathrm{tCa}$ and $\mathrm{tMg}$, and
\end{abstract}

Received August 25, 2017.

Accepted November 14, 2017.

${ }^{1}$ Corresponding author: jepsantos@ufl.edu feeding calcidiol tended to increase colostrum yield and increased losses of $\mathrm{tCa}$ and $\mathrm{tMg}$ in colostrum. Cows fed the diet with negative DCAD had increased concentrations of serotonin and C-terminal telopeptide of type 1 collagen prepartum compared with cows fed the diet with positive DCAD. Concentrations of undercarboxylated and carboxylated osteocalcin and those of adiponectin did not differ with treatment. These results provide evidence that dietary manipulations can induce metabolic adaptations that improve mineral homeostasis with the onset of lactation that might explain some of the improvements observed in health and production when cows are fed diets with negative DCAD or supplemented with calcidiol.

Key words: calcidiol, calcium, dietary cation-anion difference (DCAD), vitamin D

\section{INTRODUCTION}

Nutritional interventions applied in the precalving period can have a prolonged positive effect on dairy cow production and health well into lactation, in particular prepartum dietary interventions that prevent mineralrelated disorders in early lactation (Block, 1994; Lean et al., 2006). Calcium metabolism is critical during the transition period because of the increased demands for fetal skeletal growth (House and Bell, 1993) and irreversible loss of $\mathrm{Ca}$ in milk at the onset of lactation (Ramberg et al., 1970), which explain the high incidence of transitory and prolonged hypocalcemia, especially in multiparous cows. In some cases, cows with hypocalcemia develop clinical signs of disease, also called milk fever, which markedly increases the risk of other diseases (Curtis et al., 1983; Martinez et al., 2012). Bone is a reservoir of $\mathrm{Ca}$ and $\mathrm{P}$, but bone $\mathrm{Ca}$ reserves are limited, and cows must have effective enteric uptake of $\mathrm{Ca}$ to meet lactational demands. The skeleton also plays 
other roles in adaptation to lactation and is the source of osteocalcin ( $\mathbf{O C})$, produced by mature osteoblasts. Osteocalcin concentrations are directly proportional to $\mathrm{Ca}$ and $\mathrm{P}$ concentrations in dairy cows at the onset of lactation (Naito et al., 1990).

Vitamin D plays a central role in mineral metabolism, regulating the absorption of $\mathrm{Ca}$ and $\mathrm{P}$ from the gut, mobilizing mineral from bone, and stimulating renal Ca reabsorption (Bronner, 1987). Reductions of blood ionized $\mathrm{Ca}(\mathbf{i C a})$ trigger the synthesis and release of parathyroid hormone (PTH), which regulates a cascade of metabolic responses, including the hydroxylation and consequent activation of 25-hydroxyvitamin $\mathrm{D}_{3}$ to 1,25 -dihydroxyvitamin $\mathrm{D}_{3}$ (Fraser and Kodicek, $1973)$ by directly acting on the $1 \alpha$-hydroxylase gene CYP27B1 (Brenza and DeLuca, 2000). Supplementation with 1,25-dihydroxyvitamin $\mathrm{D}_{3}$, but not vitamin $\mathrm{D}_{3}$ or 25-hydroxyvitamin $\mathrm{D}_{3}$ (Taylor et al., 2008), increased blood concentrations of $\mathrm{OC}$ and $\mathrm{Ca}$ in nonlactating dairy cows (Kim et al., 2011). Furthermore, iCa concentrations increased in transition dairy cows receiving a combination of 25-hydroxyvitamin $\mathrm{D}_{3}$ and a diet with negative DCAD (Wilkens et al., 2012). Rodney et al. (2018) identified weak positive correlations between plasma calcidiol and OC concentrations over time in mid-lactation dairy cows, although further work is required to better understand whether similar relationships exist during the transition period.

Bone and Ca metabolism are highly integrated with energy metabolism, and a major role for skeleton and Ca metabolism in integrating metabolic adaptations to lactation has been proposed (Lee et al., 2007; Lean et al., 2014). Elegant murine studies demonstrated the integration of OC and energy metabolism through effects on insulin and glucose (Lee et al., 2007). In dairy cattle, hypocalcemia greatly increases the risk of other diseases that affect metabolism, and below-normal concentrations of $\mathrm{iCa}$ and total $\mathrm{Ca}$ (tCa) impair insulin release and result in increased lipolysis (Martinez et al., 2014), which has implications for energy metabolism during early lactation when adipose tissue insulin sensitivity is depressed and response to lipolytic signals enhanced (McNamara, 1991).

Dietary interventions that influence $\mathrm{Ca}$ and mineral metabolism include, but are not limited to, altering the DCAD of prepartum diets (Block, 1984) and manipulating the source of vitamin D supplied in the diet (Wilkens et al., 2012). We hypothesized that 25-hydroxyvitamin $\mathrm{D}_{3}$ would be more effective than vitamin $\mathrm{D}_{3}$ in improving $\mathrm{Ca}$ homeostasis in transition dairy cows, particularly when fed with an acidogenic diet, which would reflect on a more integrated bone and mineral metabolism. Therefore, the objectives of the present experiment were to explore the individual and combined effects of diets with differing DCAD levels, alkalogenic or acidogenic, and vitamin D treatments, either cholecalciferol or calcidiol or 25-hydroxyvitamin $\mathrm{D}_{3}$, during the prepartum period on vitamin $\mathrm{D}$, mineral, and bone metabolism. This paper is 1 of 3 companion papers (Martinez et al., 2018a,b) from an experiment designed to examine the effects of level of DCAD and source of dietary vitamin $\mathrm{D}$ on vitamin $\mathrm{D}$, mineral, and energy metabolism and implications for postpartum performance and health.

\section{MATERIALS AND METHODS}

The University of Florida Institutional Animal Care and Use Committee approved procedures with cows under the protocol number 201408331. Throughout the article, the vitamins fed will be referred to as cholecalciferol $(\mathbf{C H})$ and calcidiol (CA), whereas the same vitamins measured in blood plasma will be referred as vitamin $\mathrm{D}_{3}$ and 25-dihydroxyvitamin $\mathrm{D}_{3}$.

\section{Cows and Housing}

Eighty pregnant dry Holstein cows, 28 nulliparous and 52 parous, were enrolled in the experiment at the University of Florida Dairy Unit between February and August 2014. Cows were moved into the experimental pen to acclimate to the facilities and fed a common diet for the first few days. Cows were assigned to individual feeding gates (Calan Broadbent feeding system, American Calan Inc., Northwood, NH) based on the sequence of enrollment. One parous cow was removed from the data analyses because of diagnosis of lymphosarcoma during late gestation. Therefore, 79 cows were included in all statistical analyses. Details of enrollment criteria and housing can be found elsewhere (Martinez et al., 2018a). For consistency of terminology throughout the article, cows are referred to as either nulliparous (those that were nulliparous prepartum and primiparous postpartum) or parous (those that had previously calved).

\section{Treatment Diets and Feeding}

The experiment followed a randomized complete block design with cow as the experimental unit. Weekly cohorts of prepartum cows at $252 \mathrm{~d}$ of gestation were blocked by parity as nulliparous or parous, with parous cows also blocked by previous lactation 305-d milk yield and, within each block, assigned randomly to 1 of the 4 treatments. Treatments were arranged as a factorial with 2 levels of DCAD, positive $(+130 \mathrm{mEq} /$ $\mathrm{kg})$ or negative $(-130 \mathrm{mEq} / \mathrm{kg})$, and 2 sources of vi- 
tamin $\mathrm{D}, \mathrm{CH}$ or $\mathrm{CA}$, fed at $3 \mathrm{mg}$ for each $11 \mathrm{~kg}$ of diet DM. The vitamin D products were provided as cholecalciferol (Rovimix $\mathrm{D}_{3}, 300 \mathrm{mg}$ of cholecalciferol per kg; Division of Animal Nutrition and Health, DSM Nutritional Products LLC, Parsippany, NJ) or calcidiol (Hy-D, a product containing $153 \mathrm{mg}$ of calcidiol per kg; DSM Nutritional Products LLC). Prepartum cows were expected to consume $11 \mathrm{~kg}$ of $\mathrm{DM} / \mathrm{d}$ in the last $21 \mathrm{~d}$ of gestation, which would result in intake of 3 $\mathrm{mg}$ of either $\mathrm{CH}$ or $\mathrm{CA}$. Therefore, the 4 treatments were positive DCAD with cholecalciferol $(\mathbf{P C H} ; 7$ nulliparous and 12 parous), positive DCAD with calcidiol (PCA; 7 nulliparous and 13 parous), negative DCAD with cholecalciferol (NCH; 7 nulliparous and 13 parous), and negative DCAD with calcidiol (NCA; 7 nulliparous and 13 parous). Treatment diets were fed from $252 \mathrm{~d}$ of gestation to calving. Upon calving, cows were fed the same lactation ration for the first 49 DIM. All diets were fed as TMR as depicted in Table 1. Details of feed sampling and analytical methods are presented in Martinez et al. (2018a), and chemical analyses of diets are given in Table 1.

Cows were fed diets as TMR once daily prepartum, at approximately $0730 \mathrm{~h}$, and twice daily postpartum, at 0730 and $1230 \mathrm{~h}$. Refusals were weighed once daily, before the morning feeding, and feed allowances were calculated daily with a goal of $5 \%$ refusals.

\section{Measurements of Colostrum Yield and Mineral Content}

Cows were milked within the first $6 \mathrm{~h}$ after calving, and colostrum yield was measured and duplicate samples were collected, frozen at $-20^{\circ} \mathrm{C}$, and later analyzed for concentrations of $\mathrm{tCa}$ and total $\mathrm{Mg}$ (tMg). Throughout the experiment, cows were milked twice daily at 0700 and $1900 \mathrm{~h}$; yields of milk and milk components are reported in Martinez et al. (2018a).

Samples of colostrum were thawed, thoroughly homogenized, and pipetted into triplicate aliquots of 2.5 $\mathrm{mL}$ into $50-\mathrm{mL}$ tubes. Twenty-five milliliters of $24 \%$ trichloroacetic acid and $22.5 \mathrm{~mL}$ of deionized water were added to each tube. Samples were agitated and homogenized every $5 \mathrm{~min}$ for $30 \mathrm{~min}$. The solution was filtered and a $5-\mathrm{mL}$ aliquot of the filtrate was transferred to a $50-\mathrm{mL}$ tube. One milliliter of $5 \%$ lanthanum chloride and $44 \mathrm{~mL}$ of deionized water were added to each tube to result in a 50-mL solution. Samples were then analyzed by atomic absorption using a spectrophotometer (AAnalyst 200, Perkin-Elmer Inc., Waltham, $\mathrm{MA}$ ) equipped with $\mathrm{Ca}$ - and $\mathrm{Mg}$-specific hollow cathode lamps. The intraassay coefficient of variation $(\mathbf{C V})$ averaged 4.6 and $5.2 \%$ for concentrations of tCa and
tMg in colostrum, respectively. The amounts of tCa and $\mathrm{tMg}$ secreted in colostrum were calculated based on yields of colostrum and the respective concentrations of $\mathrm{tCa}$ and $\mathrm{tMg}$.

\section{Blood Sampling and Processing}

Blood was collected 3 times per week from $265 \mathrm{~d}$ of gestation until calving, and on d $0,1,2,3,6,9,12$, $15,18,21,24,27$, and 30 postpartum, by puncture of the coccygeal vein or artery into evacuated tubes (Vacutainer, Becton Dickinson, Franklin Lakes, NJ). Tubes contained no anticoagulant agents for serum separation and $\mathrm{K}_{2}$ EDTA or lithium heparin for plasma separation. For the prepartum period, only the last 4 samples relative to calving were used for analysis. Serum samples were allowed to clot at room temperature and then placed in ice until processing. Samples with anticoagulant were placed in ice until processing within $4 \mathrm{~h}$ of collection. Tubes were centrifuged for $15 \mathrm{~min}$ at $2,500 \times g$ for plasma or serum separation. Plasma and serum samples were transferred into multiple aliquots of $0.5,1.0$, or $2.0 \mathrm{~mL}$ and stored frozen at -20 or $-80^{\circ} \mathrm{C}$ until analyses. All assays performed followed the initial randomization with blocks such that samples from each block were analyzed in the same assay.

\section{Sampling of Whole Blood and Measurements of lonized Ca and Acid-Base Measures}

Whole blood was sampled by puncture of the jugular vein on $\mathrm{d}-9,-6,-3,-1,0,1,2,3$, and 6 relative to calving and analyzed within 1 to 3 min for concentrations of $\mathrm{iCa}, \mathrm{pH}, \mathrm{HCO}_{3}$, base excess, and partial pressure of $\mathrm{O}_{2}\left(\mathbf{p O}_{2}\right)$ and $\mathrm{CO}_{2}\left(\mathbf{p C O}_{2}\right)$ using a handheld biochemical analyzer (VetScan i-STAT, Abaxis, Union City, CA).

\section{Plasma Vitamin D Metabolites}

Plasma sampled on $\mathrm{d}-6,-3,-1,0,1,2,3,6,9$, and 12 relative to calving was analyzed for concentrations of vitamin $\mathrm{D}_{3}, 25$-hydroxyvitamin $\mathrm{D}_{3}, 25$-hydroxyvitamin $\mathrm{D}_{2}, 3$-epi-25-hydroxyvitamin $\mathrm{D}_{3}, 1,25$-dihydroxyvitamin $\mathrm{D}_{3}$, and 24,25-dihydroxivitamin $\mathrm{D}_{3}$ using HPLC coupled with MS detection by the Analytical Research Center of DSM Nutritional Products (Kaiseraugst, Switzerland). Personnel running the assays were blind to treatments. The lower limits of quantification for the assays were $0.5 \mathrm{ng} / \mathrm{mL}$ for vitamin $\mathrm{D}_{3}, 25$-hydroxyvitamin $\mathrm{D}_{2}$, 3-epi-25-hydroxyvitamin $\mathrm{D}_{3}$ and 24,25-hydroxyvitamin $\mathrm{D}_{3} ; 1.0 \mathrm{ng} / \mathrm{mL}$ for 25 -hydroxyvitamin $\mathrm{D}_{3}$; and $10 \mathrm{pg} /$ $\mathrm{mL}$ for 1,25 -hydroxyvitamin $\mathrm{D}_{3}$. 
Table 1. Dietary ingredients and nutrient composition of diets fed pre- and postpartum

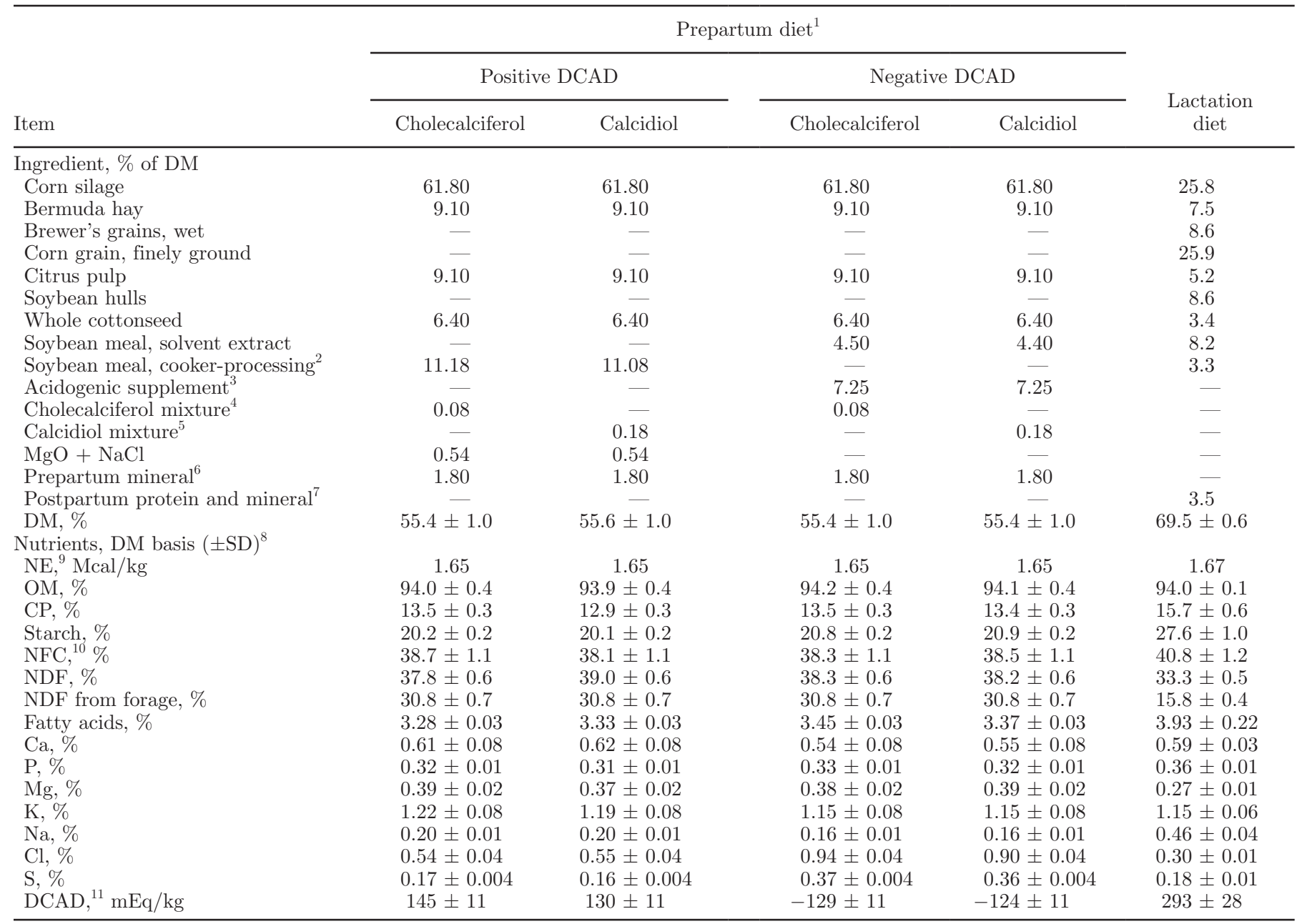

${ }^{1}$ Prepartum cows starting at $252 \mathrm{~d}$ of gestation were fed diets with either a positive $(+130 \mathrm{mEq} / \mathrm{kg})$ or a negative $(-130 \mathrm{mEq} / \mathrm{kg}) \mathrm{DCAD}$. Within each DCAD diet, cows were fed either $3 \mathrm{mg}$ of cholecalciferol or $3 \mathrm{mg}$ of calcidiol.

${ }^{2}$ Amino Plus (cooker-processing soybean meal; Ag Processing Inc., Emmetsburg, IA).

${ }^{3}$ Bio-Chlor (a fermentation product containing dried condensed extracted glutamic acid fermentation product, dried condensed corn fermentation solubles, processed grain by-products, and magnesium chloride; Arm \& Hammer Animal Nutrition, Princeton, NJ).

${ }^{4}$ Rovimix $\mathrm{D}_{3}$ (a product containing $300 \mathrm{mg}$ of cholecalciferol per kg; Division of Animal Nutrition and Health, DSM Nutritional Products LLC, Parsippany, NJ).

${ }^{5} \mathrm{Hy}-\mathrm{D}$ (a product containing $153 \mathrm{mg}$ of calcidiol per kg; Division of Animal Nutrition and Health, DSM Nutritional Products LLC).

${ }^{6}$ Each kilogram contained (DM basis) $10.3 \% \mathrm{Ca}, 0.7 \% \mathrm{P}, 4.0 \% \mathrm{Mg}, 0.9 \% \mathrm{~K}, 0.25 \% \mathrm{~S}, 1.8 \% \mathrm{Na}, 2.7 \% \mathrm{Cl}, 1,750 \mathrm{mg}$ of $\mathrm{Zn}, 600 \mathrm{mg}$ of $\mathrm{Cu}, 1,090$ $\mathrm{mg}$ of $\mathrm{Mn}, 21 \mathrm{mg}$ of Se, $75 \mathrm{mg}$ of Co, $21 \mathrm{mg}$ of I, 260,000 IU of vitamin A, and 7,500 IU of vitamin E.

${ }^{7}$ A supplement containing 30\% blood meal enriched with rumen-protected lysine and methionine (LysAAMet, Perdue Ag Solutions LLC, Salisbury, MD). Each kilogram contained (DM basis) $26.4 \% \mathrm{CP}, 5.1 \% \mathrm{Ca}, 1.6 \% \mathrm{P}, 4.1 \% \mathrm{Mg}, 6.8 \% \mathrm{~K}, 0.3 \% \mathrm{~S}, 10.7 \% \mathrm{Na}, 2.5 \% \mathrm{Cl}, 665 \mathrm{mg}$ of $\mathrm{Zn}$, $230 \mathrm{mg}$ of $\mathrm{Cu}, 416 \mathrm{mg}$ of $\mathrm{Mn}, 7.2 \mathrm{mg}$ of Se, $24 \mathrm{mg}$ of Co, $13.6 \mathrm{mg}$ of I, 110,000 IU of vitamin A, 33,000 IU of cholecalciferol (0.825 mg), 1,100 IU of vitamin E, and $460 \mathrm{mg}$ of monensin (Rumensin 90, Elanco Animal Health, Eli Lilly and Co., Indianapolis, IN).

${ }^{8}$ Samples collected weekly and composited monthly for chemical analyses.

${ }^{9}$ Calculated based on the chemical analysis of dietary ingredients and using the NRC (2001) for a DMI of $12.0 \mathrm{~kg} / \mathrm{d}$ prepartum and $18 \mathrm{~kg} / \mathrm{d}$ postpartum.

${ }^{10}$ Calculated using the equation $\mathrm{DM}-[\mathrm{CP}+\mathrm{NDF}+$ fat + ash $-(\mathrm{NDF}$ insoluble protein $)]$.

${ }^{11}$ Calculated using the equation $[(\mathrm{mEq}$ of $\mathrm{Na}+\mathrm{mEq}$ of $\mathrm{K})-(\mathrm{mEq}$ of $\mathrm{Cl}+\mathrm{mEq}$ of $\mathrm{S})]$. 


\section{Measurements of Serum Concentrations of $t \mathrm{Ca}, \mathrm{tMg}$, and Total $P$}

Concentrations of tCa, tMg, and total $\mathrm{P}(\mathbf{t P})$ were analyzed in serum samples collected on $\mathrm{d}-9,-6,-3$, $-1,0,1,2,3,6,9,12,15,18,21,24,27$, and 30 relative to calving in duplicates. Samples were analyzed for tCa and tMg by atomic absorption (AAnalyst 200, Perkin-Elmer Inc.) as previously described by Martinez et al. (2012). Intra- and interassay CV were, respectively, 1.6 and $3.3 \%$ for $\mathrm{tCa}$, and 2.0 and $2.8 \%$ for $\mathrm{tMg}$. Concentrations of tP were quantified in serum using the molybdenum blue method (Quinlan and DeSesa, 1955). The intra- and interassay CV were, respectively, 6.0 and $8.0 \%$.

\section{Measurements of Concentrations of PTH, Serotonin, C-Terminal Telopeptide of Type 1 Collagen, Undercarboxylated and Carboxylated OC, and Adiponectin}

Personnel performing the assays were blind to treatments. Plasma sampled on $\mathrm{d}-6,-3,-1,0,1,2,3,6$, and 9 relative to calving was analyzed for concentrations of PTH by ELISA (cat. no. 60-3500; Immutopics, Athens, OH) at the Heartland Assays laboratory (Heartland Assays LLC, Ames, IA). The intra- and interassay CV were, respectively, 5.5 and $5.6 \%$.

Serum samples collected on $\mathrm{d}-9,-6,-3,-1,0,1$, 2,3 , and 6 relative to calving were analyzed for concentrations of serotonin using an enzyme immunoassay (Serotonin EIA Kit, Beckman Coulter Inc., Brea, CA). Intra- and interassay CV were, respectively, 11.2 and $13.2 \%$.

Serum samples collected on $\mathrm{d}-1,0,1,2$, and 3 postpartum were analyzed for the bone resorption marker C-terminal telopeptide of type 1 collagen (CTX-1) by ELISA (cat. no. AC-02F1; IDS, The Boldons, UK), and the intra- and interassay $\mathrm{CV}$ were, respectively, 2.2 and $7.7 \%$.

Plasma samples collected on $\mathrm{d}-1,0,1,2$, and 3 relative to calving were analyzed for undercarboxylated (uOC) and carboxylated (cOC) osteocalcin by ELISA (cat. no. MK118 and MK111; Clontech Labs, Takara Bio Inc., Mountain View, CA). The intra- and interassay $\mathrm{CV}$ were, respectively, 5.2 and $8.3 \%$ for uOC, and 3.7 and $1.4 \%$ for cOC.

Plasma samples collected on $\mathrm{d}-9,-6,-3,-1,0,1$, $2,3,6,9,12,15,18,21,24,27$, and 30 were analyzed for concentrations of adiponectin by ELISA conducted by CSIRO Agriculture (St Lucia, QLD, Australia). The intra and interassay $\mathrm{CV}$ were, respectively, 11.9 and $10.2 \%$.
Urine Collection and Analysis. Urine samples were collected twice weekly prepartum and at 3 and 7 DIM by massaging the perineal area until a copious stream of urine was obtained. Samples were placed in plastic tubes in ice and the $\mathrm{pH}$ was measured within 10 min of collection using a portable $\mathrm{pH}$ meter (B-712 LAQUA twin, Horiba Scientific, Edison, NJ). Samples were then frozen at $-20^{\circ} \mathrm{C}$ for later analyses. Prepartum samples collected closest to $\mathrm{d}-7$ and -3 , and those collected on d 3 and 7 relative to calving were used for statistical analyses of effects of treatments on $\mathrm{pH}$.

Prepartum samples collected closest to $\mathrm{d}-5$ and those collected on d 3 relative to calving were used for determinations of creatinine, $\mathrm{tCa}$, and $\mathrm{tMg}$ concentrations. Samples were analyzed in triplicates for creatinine using a commercial colorimetric method (Creatinine Urinary Detection Kit, Arbor Assays, Ann Arbor, MI). The intra- and interassay $\mathrm{CV}$ for creatinine were 2.4 and $7.6 \%$, respectively. Triplicate urine samples were diluted 1 to 400 with $0.5 \%$ lanthanum chloride, and concentrations of tCa and $\mathrm{tMg}$ were analyzed by atomic absorption using a spectrophotometer equipped with Ca- and Mg-specific hollow cathode lamps (AAnalyst 200, Perkin-Elmer Inc.). Urinary tCa and tMg assays were performed as a single run and the intraassay CV were 4.4 and $2.1 \%$, respectively.

Creatinine was used as a marker to estimate daily urinary volume based on the constant excretion of 29 mg of creatinine per $\mathrm{kg}$ of BW per day (Valadares et al., 1999). The estimate of daily urinary volume was calculated for the pre- and postpartum periods using the mean BW of each cow in the last week of gestation and first week postpartum. The estimate of daily urinary volume was calculated as follows: BW $(\mathrm{kg}) \times$ $29 /$ urinary concentrations of creatinine ( $\mathrm{mg} / \mathrm{L})$. Daily urinary excretions of $\mathrm{tCa}$ and $\mathrm{tMg}$ were calculated as the product of urinary volume and the respective concentrations of those minerals in the urine samples.

Estimated Mineral Balance. Estimated Ca and $\mathrm{Mg}$ balances were calculated in the last week of gestation and first 3 DIM based on measurements of DMI, concentrations of $\mathrm{Ca}$ and $\mathrm{Mg}$ in diets, urinary $\mathrm{Ca}$ and $\mathrm{Mg}$ losses, and $\mathrm{Ca}$ and $\mathrm{Mg}$ losses in colostrum and milk. Estimated absorptions of $\mathrm{Ca}$ and $\mathrm{Mg}$ and fetal tissues accretion were computed using the NRC (2001) according to diet and calf BW at birth. We assumed no accretion of minerals in the last week of gestation by dams other than accretion into fetal tissues. We also assumed no sequestration of $\mathrm{Ca}$ by the mammary gland before secretion of colostrum because of lack of accurate data, although $\mathrm{Ca}$ secreted in colostrum might be sequestered in the gland days before calving (Visek et 
al., 1953); it has been calculated as zero in Ca balance studies in prepartum cows (Ramberg et al., 1970).

\section{Statistical Analysis}

The experiment followed a randomized complete block design with cow as the experimental unit. All data were analyzed by ANOVA and results for the pre- and postpartum periods were analyzed separately. Normality of residuals and homogeneity of variance were examined for each continuous dependent variable analyzed after fitting the statistical model. Responses that violated the assumptions of normality were subjected to power transformation according to the BoxCox procedure (Box and Cox, 1964) using the PROC TRANSREG in SAS (SAS ver. 9.4, SAS Institute Inc., Cary, NC). The least squares means and standard errors of the means were back transformed for presentation according to Jørgensen and Pedersen (1998). Concentrations of vitamin $\mathrm{D}_{3}, 1,25$-dihydroxyvitamin $\mathrm{D}_{3}$, 24,25-dihydroxyvitamin $\mathrm{D}_{3}, \mathrm{PTH}$, serotonin, uOC, and $\mathrm{cOC}$ had to be log-transformed before analyses either because of heteroscedasticity or because residuals were not normally distributed.

Data were analyzed by mixed models using the MIXED procedure of SAS (SAS Institute Inc.). Responses with a single measurement per cow were analyzed with the fixed effects of level of DCAD (positive vs. negative), source of vitamin $\mathrm{D}(\mathrm{CH}$ vs. $\mathrm{CA})$, interaction between DCAD and vitamin D, parity (nulliparous vs. parous), and the interactions between DCAD and parity, vitamin $\mathrm{D}$ and parity, and DCAD and vitamin $\mathrm{D}$ and parity, and the random effect of block. Data with repeated measures within experimental units were analyzed with the same mixed model described above, but also included the fixed effects of day, and the interactions between DCAD and day, vitamin D and day, parity and day, DCAD and vitamin D and day, DCAD and parity and day, vitamin D and parity and day, and DCAD and vitamin D and parity and day. Cow nested within DCAD and vitamin D was a random effect in the model. The Repeated statement was included in all mixed models with repeated measurements with day specified as the repeated effect. The covariance structure was modeled based on spacing between measurements and selection was based on model fit that resulted in the smallest corrected Akaike's information criterion. The Kenward-Roger method was used to compute the approximate denominator degrees of freedom for the $\mathrm{F}$ tests in the statistical models. When an interaction was significant, pairwise comparisons were performed with the adjustment of Tukey. Statistical significance was considered at $P \leq 0.05$, and tendency was considered at $0.05<P \leq 0.10$.

\section{RESULTS}

Of the 79 cows included in the statistical analyses, 1 PCA cow developed pneumonia because of aspiration of an oral Ca drench used to treat clinical hypocalcemia; she had to be euthanized, was removed prematurely from the experiment, and contributed data from enrollment to 2 DIM. Therefore, analyses of data until 2 DIM included 79 cows, whereas data collected after 2 DIM included 78 cows.

\section{Vitamin D Metabolites}

Cows fed the positive DCAD had greater $(P=$ 0.005) vitamin $\mathrm{D}_{3}$ concentrations in plasma prepartum than those fed the negative DCAD (positive $=4.60$ vs. negative $=3.45 \mathrm{ng} / \mathrm{mL}$ ), and feeding $\mathrm{CH}$ markedly increased $(P<0.001)$ plasma concentrations of vitamin $\mathrm{D}_{3}$ prepartum compared with feeding $\mathrm{CA}(\mathrm{CH}$ $=14.68$ vs. $\mathrm{CA}=1.08 \mathrm{ng} / \mathrm{mL}$; Table 2$)$. The differences in concentrations of vitamin $\mathrm{D}_{3}$ prepartum with treatments were observed equally in both nulliparous and parous cows, although nulliparous had greater $(P$ $=0.03$ ) vitamin $\mathrm{D}_{3}$ concentration in plasma prepartum than parous cows. The differences in concentrations of vitamin $\mathrm{D}_{3}$ in plasma with treatments extended during the postpartum period (Figure 1A; Table 3), although they markedly declined in cows fed $\mathrm{CH}$, but increased slightly in cows fed CA.

Similar to vitamin $\mathrm{D}_{3}$, concentrations of 25-hydroxyvitamin $\mathrm{D}_{3}$ were greater $(P=0.003)$ throughout the prepartum period in cows fed the positive than those fed the negative DCAD, which averaged 161.6 and $135.1 \mathrm{ng} / \mathrm{mL}$, respectively (Table 1, Figure 1B). As anticipated, feeding CA increased $(P<0.001)$ plasma concentrations of 25-hydroxyvitamin $\mathrm{D}_{3}$ 4-fold $(\mathrm{CH}=$ 59.7 vs. $\mathrm{CA}=237.0 \mathrm{ng} / \mathrm{mL}$ ), but the increment was greater in cows fed positive DCAD compared with negative DCAD. No differences between parity groups or interactions between treatment and parity were observed for prepartum concentrations of 25-hydroxyvitamin $\mathrm{D}_{3}$. Concentrations of 25-hydroxyvitamin $\mathrm{D}_{3}$ during the postpartum period remained elevated in cows fed CA compared with those fed $\mathrm{CH}(\mathrm{CH}=58.5$ vs. $\mathrm{CA}=218.1 \mathrm{ng} / \mathrm{mL}$; Figure $1 \mathrm{~B})$; however, a tendency $(P=0.06)$ for interaction between DCAD and vitamin D was observed because the increase in 25-hydroxyvitamin $\mathrm{D}_{3}$ was greater in cows fed positive compared with negative DCAD (Table 3). The concentrations of 25-hydroxyvitamin $\mathrm{D}_{3}$ in plasma of individual cows fed $3 \mathrm{mg}$ of $\mathrm{CH}$ for the last $3 \mathrm{wk}$ of gestation did not exceed $90 \mathrm{ng} / \mathrm{mL}$ either in the pre- or postpartum period (Figure 2A and 2B), whereas cows fed CA maintained concentrations of vitamin $\mathrm{D}_{3}$ always below $4 \mathrm{ng} / \mathrm{mL}$. 


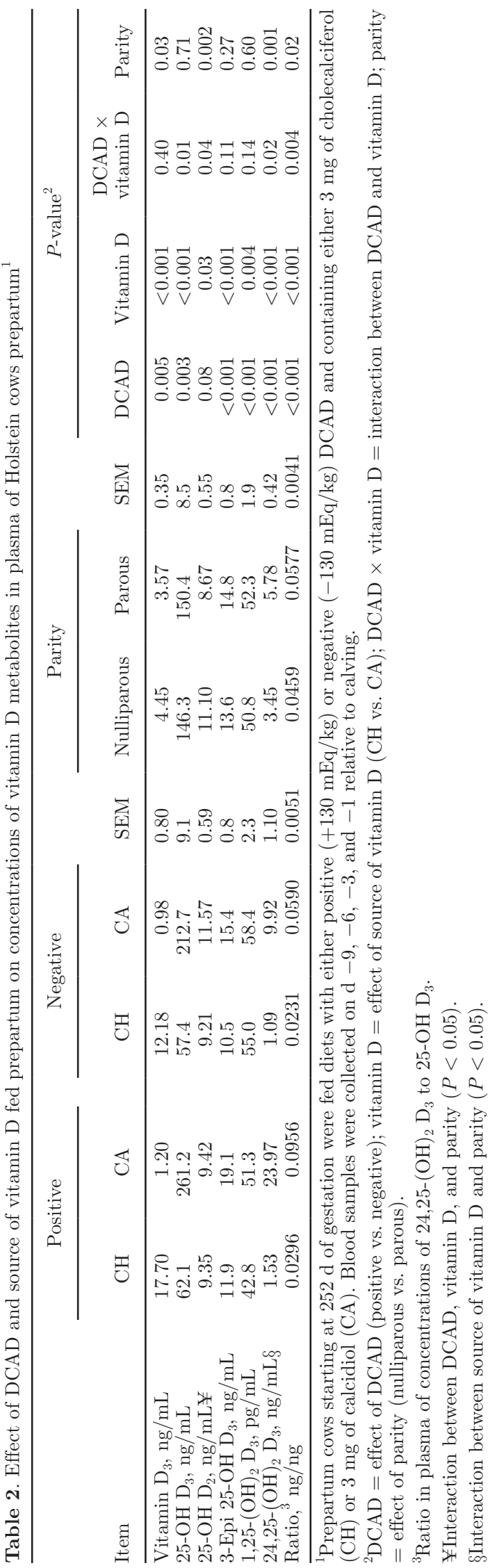

Prepartum plasma concentrations of 25-hydroxyvitamin $\mathrm{D}_{2}$ were affected by the interaction $(P=0.04)$ between DCAD and vitamin $\mathrm{D}$ source because cows fed NCA had greater concentrations than those fed the other 3 treatments (Table 2; Figure 1C). The differences prepartum extended postpartum (Table 3) when all cows were fed the same diet. Parity group affected $(P<0.02)$ concentrations of 25 -hydroxyvitamin $\mathrm{D}_{2}$ during the pre- and postpartum periods (Tables 2 and 3 ). Nevertheless, an interaction $(P=0.04)$ among DCAD, vitamin $\mathrm{D}$, and parity was detected for concentrations of 25-hydroxyvitamin $\mathrm{D}_{2}$ prepartum because the increment in plasma concentrations with feeding NCA was greater in nulliparous than in parous cows.

Feeding a diet with positive DCAD increased $(P<$ $0.001)$ prepartum concentrations of 3-epi 25-hydroxyvitamin $\mathrm{D}_{3}$ compared with feeding a diet with negative DCAD (positive $=15.5$ vs. negative $=12.9 \mathrm{ng} / \mathrm{mL}$; Table 2), and the differences were extended to the postpartum period $($ positive $=14.3$ vs. negative $=12.3$ $\mathrm{ng} / \mathrm{mL}$; Figure 1D and Table 3). Similarly, feeding CA compared with $\mathrm{CH}$ increased $(P<0.001)$ concentrations of 3-epi 25-hydroxyvitamin $\mathrm{D}_{3}$ prepartum $(\mathrm{CH}=11.2$ vs. $\mathrm{CA}=17.2 \mathrm{ng} / \mathrm{mL}$; Table 2$)$ and postpartum $(\mathrm{CH}$ $=10.3$ vs. $\mathrm{CA}=16.4 \mathrm{ng} / \mathrm{mL}$; Table 3$)$. No differences were observed between parity groups or interactions between treatment and parity group for concentrations of 3-epi 25-hydroxyvitamin $\mathrm{D}_{3}$.

Prepartum concentrations of 1,25-dihydroxyvitamin $\mathrm{D}_{3}$ in plasma increased $(P<0.01)$ in cows fed negative compared with positive (positive $=46.9$ vs. negative $=56.7 \mathrm{pg} / \mathrm{mL}$ ) and in cows fed CA compared with $\mathrm{CH}(\mathrm{CH}=48.5$ vs. $\mathrm{CA}=54.7 \mathrm{pg} / \mathrm{mL}$; Table 2$)$. Postpartum, concentrations peaked at 2 DIM and an interaction $(P<0.05)$ between DCAD and vitamin D source were observed on $\mathrm{d} 1$ and 2 postpartum (Figure $1 \mathrm{E})$ because those fed PCA had greater concentrations than cows fed the other treatments. A tendency $(P=$ 0.06 ) for interaction between vitamin $\mathrm{D}$ and day was detected postpartum and cows fed CA had greater concentrations of 1,25-dihydroxyvitamin $\mathrm{D}_{3}$ in plasma on d 6 and 9 postpartum than cows fed $\mathrm{CH}$ (Figure 1E).

Cows supplemented with CA had a marked increase $(P<0.001)$ in concentrations of 24,25-dihydroxyvitamin $\mathrm{D}_{3}$ in plasma prepartum $(\mathrm{CH}=1.3$ vs. $\mathrm{CA}=15.4$ $\mathrm{ng} / \mathrm{mL})$, and an interaction $(P=0.02)$ between DCAD and vitamin $\mathrm{D}$ was detected because the increase was more accentuated when cows were fed the diet with positive DCAD compared with the negative DCAD (Table 2; Figure 1F). An interaction $(P<0.001)$ between source of vitamin $\mathrm{D}$ and parity was observed for concentrations of 24,25-dihydroxyvitamin $\mathrm{D}_{3}$ in plasma prepartum because within those fed $\mathrm{CH}$, nulliparous cows had only $40 \%$ of the concentration $(P<$ 

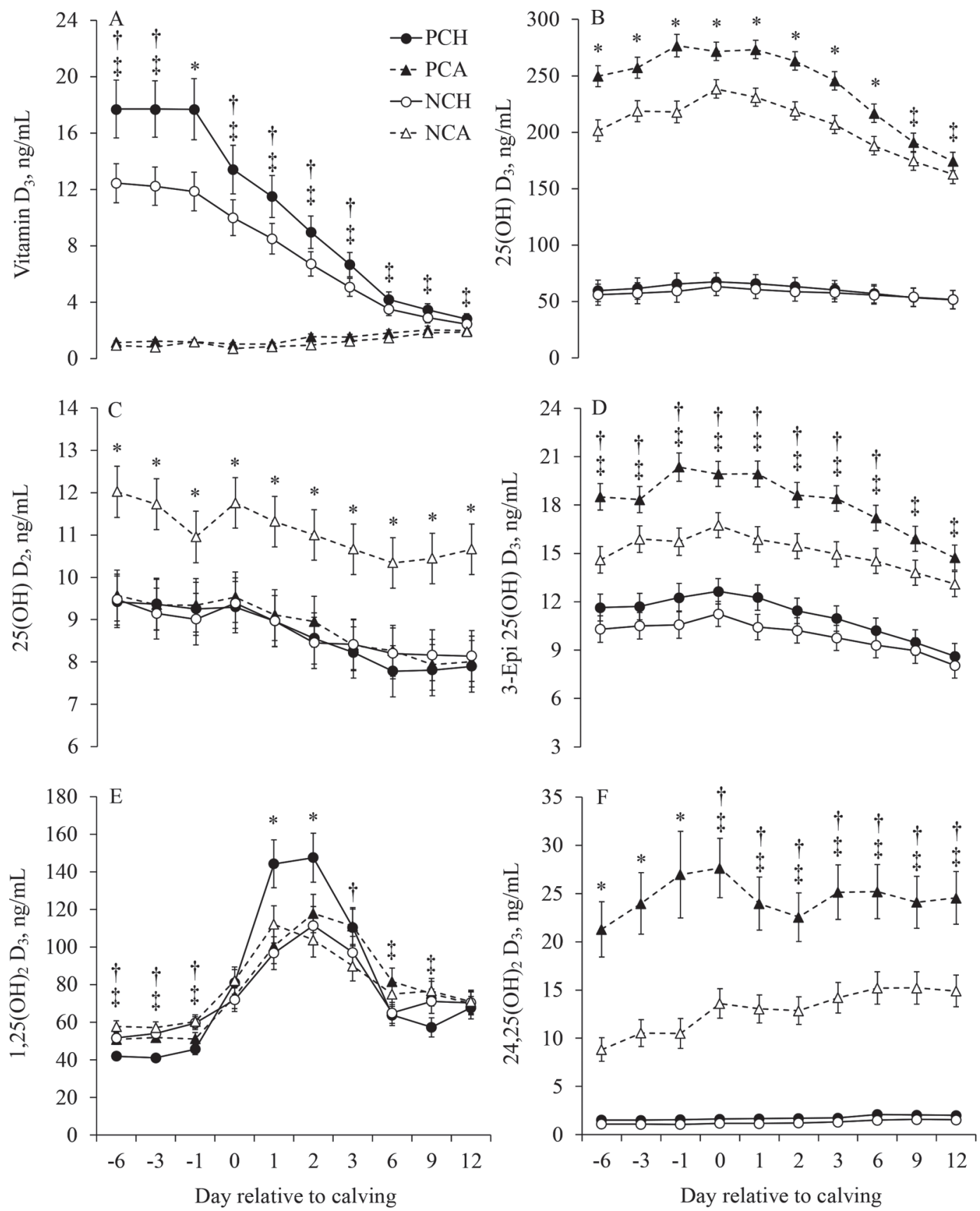

Figure 1. Concentrations of (A) vitamin $\mathrm{D}_{3}$, (B) 25-hydroxyvitamin $\mathrm{D}_{3}$, (C) 25-hydroxyvitamin $\mathrm{D}_{2}$, (D) 3-epi 25-hydroxyvitamin $\mathrm{D}_{3}$, (E) 1,25-dihydroxyvitamin $\mathrm{D}_{3},(\mathrm{~F})$ and 24,25-dihydroxyvitamin $\mathrm{D}_{3}$ in plasma of cows fed prepartum diets with either positive $(\mathrm{P},+130 \mathrm{mEq} / \mathrm{kg})$ or negative $(\mathrm{N},-130 \mathrm{mEq} / \mathrm{kg}$ ) DCAD and containing either $3 \mathrm{mg}$ of cholecalciferol (PCH and $\mathrm{NCH})$ or $3 \mathrm{mg}$ of calcidiol (PCA and NCA). Within a day, $\dagger$ denotes effect of DCAD $(P<0.05), \ddagger$ effect of vitamin D $(P<0.05)$, and $*$ interaction between DCAD and vitamin D $(P<0.05)$. Error bars represent SEM.

0.001) compared with parous cows (nulliparous $=0.82$ vs. parous $=2.04 \mathrm{ng} / \mathrm{mL}$ ), whereas within cows fed CA, no difference $(P=0.66)$ between nulliparous and parous cows was detected and concentrations averaged 14.5 and $16.4 \mathrm{ng} / \mathrm{mL}$, respectively. Figure 3 depicts a scatter plot of 24,25-dihydroxyvitamin $\mathrm{D}_{3}$ according to concentrations of 25-hydroxyvitamin $\mathrm{D}_{3}$ in plasma of nulliparous and parous cows prepartum and the differences can be visualized when cows were fed $\mathrm{CH}$. The ratio of plasma concentrations of 24,25-dihydroxyvitamin $\mathrm{D}_{3}$ to 25 -hydroxyvitamin $\mathrm{D}_{3}(\mathrm{ng} / \mathrm{ng})$ was smaller $(P$ $=0.02$ ) in nulliparous than parous cows when fed $\mathrm{CH}$ 


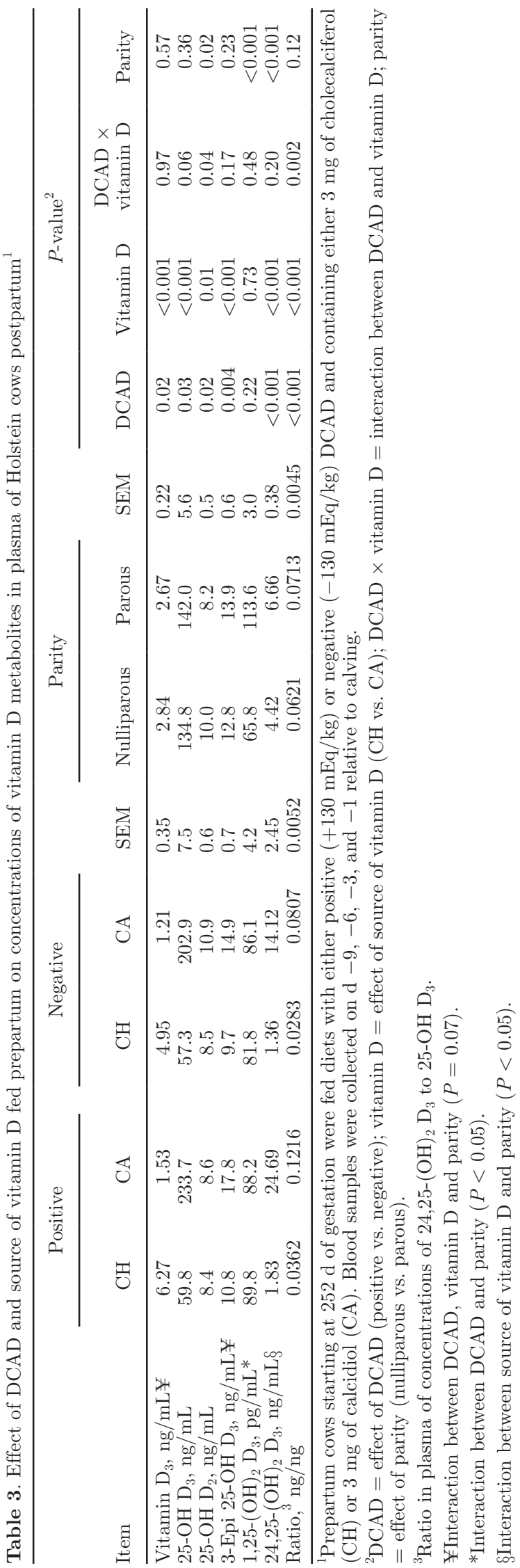

(nulliparous $=0.0171$ vs. parous $=0.0358 \pm 0.005$ ) or $\mathrm{CA}$ (nulliparous $=0.073$ vs. parous $=0.079 \pm 0.005$ ) . Postpartum concentrations of 24,25-dihydroxyvitamin $\mathrm{D}_{3}$ in plasma of dairy cows followed the same pattern as those observed prepartum (Figure $1 \mathrm{~F}$ ), and both DCAD (positive $=6.73$ vs. negative $=4.38 \mathrm{ng} / \mathrm{mL}$ ) and vitamin $\mathrm{D}$ source $(\mathrm{CH}=1.58$ vs. $\mathrm{CA}=18.67)$ affected $(P<0.001)$ concentrations of 24,25 -dihydroxyvitamin $\mathrm{D}_{3}$ (Table 3 ). As in the prepartum period, an interaction $(P<0.001)$ between vitamin $\mathrm{D}$ and parity was observed postpartum because within those fed $\mathrm{CH}$, nulliparous cows had a smaller $(P<0.001)$ concentration than parous cows (nulliparous $=1.02$ vs. parous $=$ $2.45 \mathrm{ng} / \mathrm{mL}$ ), whereas within cows fed CA, parity did not affect $(P=0.50)$ concentrations and they averaged 19.3 and $18.1 \mathrm{ng} / \mathrm{mL}$ in nulliparous and parous cows, respectively.

\section{Whole-Blood and Serum Concentrations of Minerals}

Feeding a diet with negative DCAD increased $(P$ $=0.03$ ) whole-blood concentrations of iCa prepartum (positive $=1.217$ vs. negative $=1.240 \mathrm{mM})$, but the opposite response was observed for serum tCa (positive = 2.446 vs. negative $=2.379 \mathrm{~m} M$; Table 4 ). Supplementing cows with $\mathrm{CA}$ increased $(P<0.001)$ prepartum concentrations of blood iCa $(\mathrm{CH}=1.200$ vs. $\mathrm{CA}=$ $1.257 \mathrm{mM})$ and serum tCa $(\mathrm{CH}=2.355$ vs. $\mathrm{CA}=2.470$ $\mathrm{m} M)$. Nevertheless, interactions $(P<0.05)$ among DCAD, vitamin D source, and parity were observed for iCa and tCa prepartum. For iCa, nulliparous NCA cows had the greatest concentrations prepartum, particularly on $\mathrm{d}-3$ and -1 , whereas for parous cows, those fed PCA had the greatest concentrations prepartum (Figure $4 \mathrm{~B}$ and $5 \mathrm{~A}$ ). On the other hand, for tCa, both nulliparous and parous cows fed PCA had the greatest concentrations prepartum (Figure $5 \mathrm{C}$ and $5 \mathrm{D}$ ). Feeding a diet with negative DCAD attenuated $(P<$ 0.001) the decline in blood $\mathrm{iCa}$ and serum tCa on $\mathrm{d} 0$ and 1 postpartum (Figure $4 \mathrm{~A}$ and $4 \mathrm{~B}$ ), and the benefits were observed in both nulliparous (Figure $5 \mathrm{~A}$ and $5 \mathrm{C}$ ) and parous cows (Figure 5B and 5D). Concentrations of iCa and tCa increased $(P<0.001)$ with day postpartum, and those of tCa reached a plateau earlier in nulliparous than parous cows based on the interaction $(P<0.001)$ between parity and day, at approximately 6 and 15 DIM, respectively (Figure 5C and 5D).

Prepartum concentrations of $\mathrm{tMg}$ in serum were greater $(P=0.004)$ for cows fed positive compared with negative DCAD (positive $=0.959$ vs. negative $=$ $0.909 \mathrm{mM})$ and greater $(P<0.001)$ for cows fed $\mathrm{CH}$ compared with $\mathrm{CA}(\mathrm{CH}=0.966$ vs. $\mathrm{CA}=0.901 \mathrm{mM}$; Table 4), and the differences were observed throughout the last $9 \mathrm{~d}$ of gestation (Figure $4 \mathrm{C}$ ). Concentrations of 

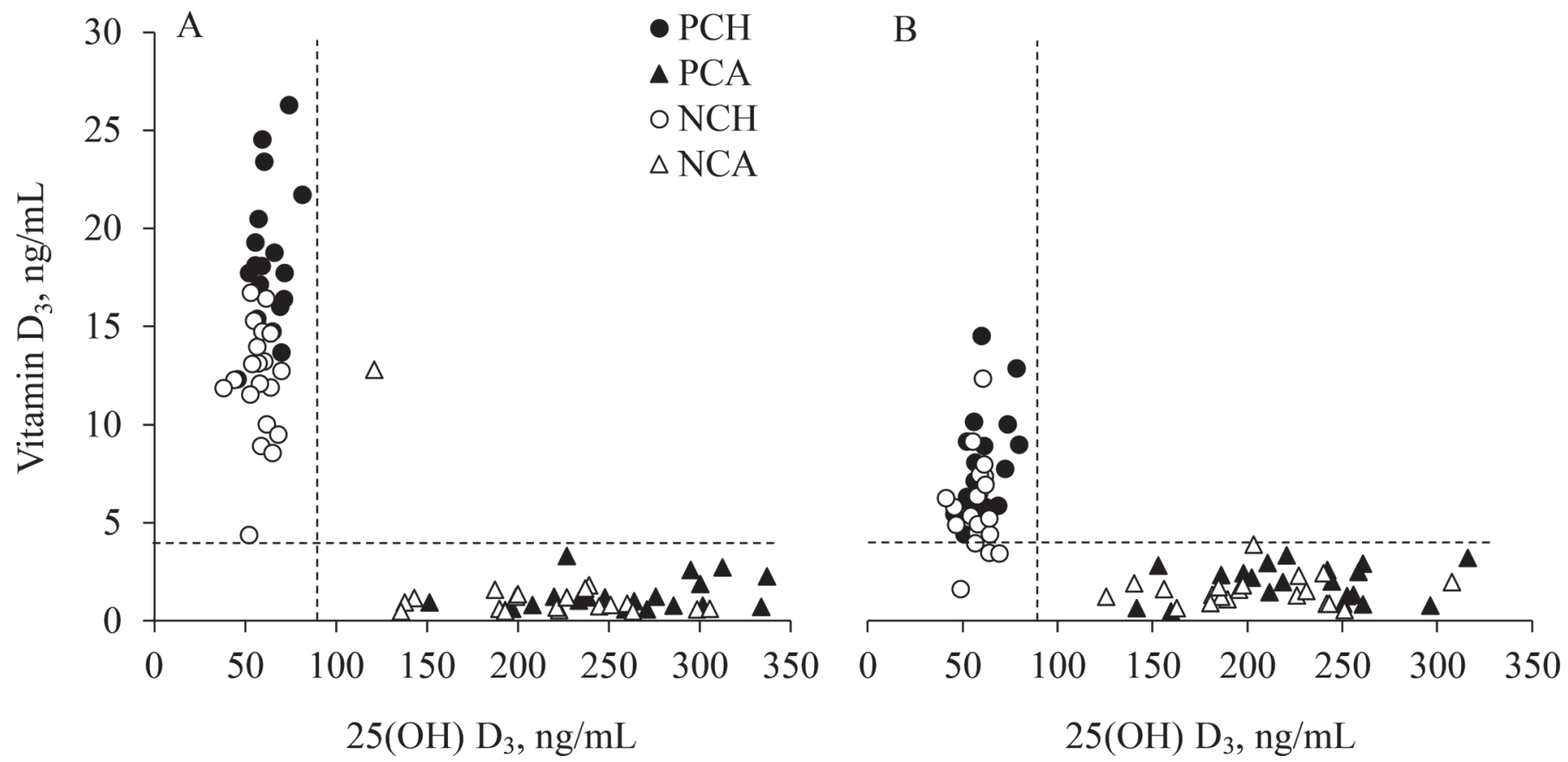

Figure 2. Scatter graphs of concentrations of vitamin $\mathrm{D}_{3}$ and 25-hydroxyvitamin $\mathrm{D}_{3}$ prepartum (A) and postpartum (B) in plasma of cows fed prepartum diets with either positive $(\mathrm{P},+130 \mathrm{mEq} / \mathrm{kg})$ or negative $(\mathrm{N},-130 \mathrm{mEq} / \mathrm{kg})$ DCAD and containing either $3 \mathrm{mg}$ of cholecalciferol ( $\mathrm{PCH}$ and $\mathrm{NCH})$ or $3 \mathrm{mg}$ of calcidiol (PCA and NCA). Values for a cow were averaged into a single mean for the pre- and postpartum periods. Dashed lines intersect at $4 \mathrm{ng} / \mathrm{mL}$ of vitamin $\mathrm{D}_{3}$ and $90 \mathrm{ng} / \mathrm{mL}$ of 25 -hydroxyvitamin $\mathrm{D}_{3}$.

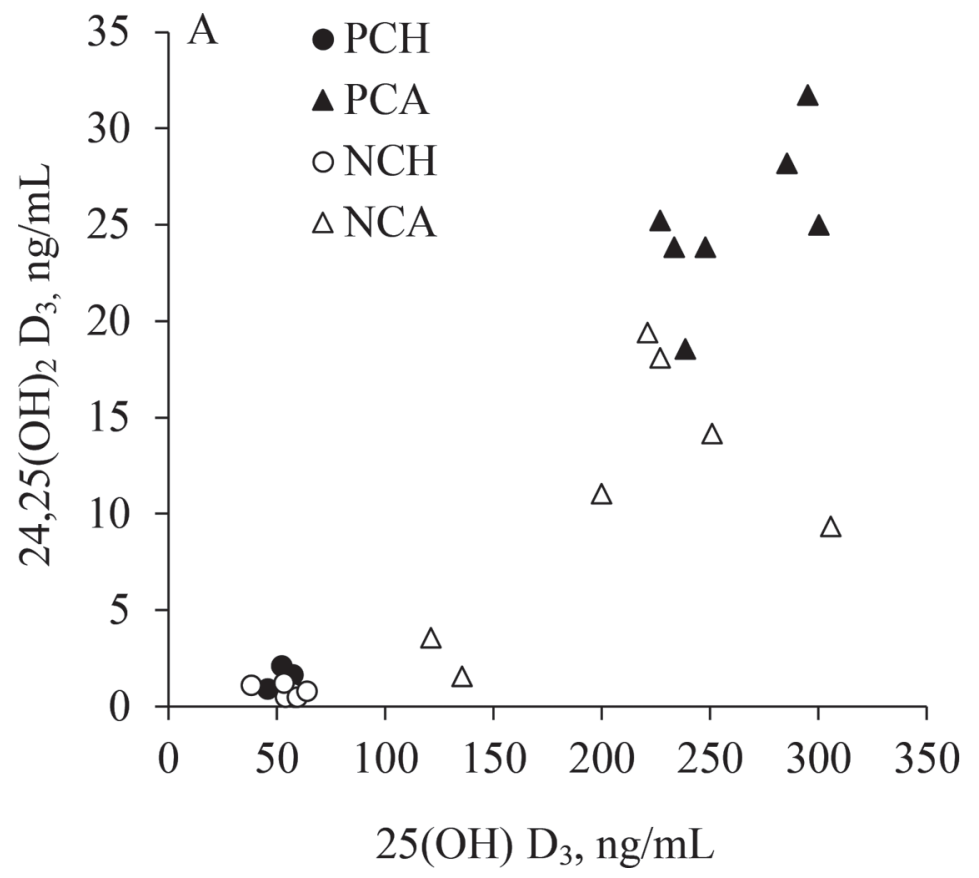

B

Figure 3. Scatter graphs of concentrations of 24,25-dihydroxyvitamin $\mathrm{D}_{3}$ and 25-hydroxyvitamin $\mathrm{D}_{3}$ prepartum in nulliparous (A) and parous (B) cows fed prepartum diets with either positive $(\mathrm{P},+130 \mathrm{mEq} / \mathrm{kg})$ or negative $(\mathrm{N},-130 \mathrm{mEq} / \mathrm{kg})$ DCAD and containing either $3 \mathrm{mg}$ of cholecalciferol (PCH and $\mathrm{NCH}$ ) or $3 \mathrm{mg}$ of calcidiol (PCA and $\mathrm{NCA}$ ). Values for a cow were averaged into a single mean for the pre- and postpartum periods. A linear relationship $\left(P<0.001 ; \mathrm{R}^{2}=0.81\right)$ was observed between 24,25 -dihydroxyvitamin $\mathrm{D}_{3}$ and 25 -hydroxyvitamin $\mathrm{D}_{3}$ prepartum. 
tMg increased $(P<0.001)$ with day postpartum in all 4 treatments (Figure $4 \mathrm{C})$. Only an interaction $(P=0.05)$ between DCAD and parity was observed postpartum because within cows fed the diet with positive DCAD, nulliparous and parous had similar $(P=0.98)$ concentrations of $\mathrm{tMg}$ postpartum (nulliparous $=0.943$ vs. parous $=0.942 \mathrm{mM})$; however, within cows fed negative DCAD, nulliparous had greater $(P=0.02) \mathrm{tMg}$ than parous cows (nulliparous $=0.982$ vs. parous $=0.900$ $\mathrm{m} M)$.

Treatment affected concentrations of tP in serum prepartum, and an interaction $(P=0.006)$ between DCAD and vitamin D was observed because feeding CA increased concentrations of tP particularly in cows fed the diet with positive DCAD (Table 4). Concentrations of tP reached a nadir on the day of calving and became relatively stable after 2 DIM in all 4 treatments (Figure 4D). No effects of treatments were observed for postpartum tP concentrations (Table 5). Neither parity group nor interactions between parity and treatment influenced concentrations of tP in serum pre- and postpartum.

Concentrations of $\mathrm{Na}$ in whole blood pre- and postpartum remained mostly unaffected by treatment (Tables 4 and 5$)$; only a tendency $(P=0.06)$ for effect of parity was observed postpartum because nulliparous had slightly lower concentrations than parous cows. Concentrations of $\mathrm{K}$ in whole blood prepartum were greater $(P=0.003)$ in cows fed negative compared with positive DCAD (positive $=3.94$ vs. negative $=$ $4.06 \mathrm{mM}$; Table 4 ), whereas vitamin $\mathrm{D}$ only tended ( $P$ $=0.09)$ to affect prepartum blood $\mathrm{K}(\mathrm{CH}=4.04$ vs. $\mathrm{CA}=3.97 \mathrm{mM})$. As in the prepartum period, blood $\mathrm{K}$ concentration was greater $(P=0.05)$ for cows fed negative compared with positive DCAD (positive $=3.82$ vs. negative $=3.92 \mathrm{~m} M$; Table 5 ), but no other effects were observed for either treatment or parity.

\section{Concentrations of Hormones and Bone Markers}

Concentrations of PTH peaked on the day of calving and then declined $(P=0.03)$ postpartum (Figure $6 \mathrm{~A})$; however, treatment did not affect concentrations either pre- or postpartum (Tables 4 and 5). Concentrations of CTX-1 increased $(P<0.001)$ with calving and remained elevated in the first 3 DIM (Figure 6B). Interactions $(P<0.05)$ between DCAD and parity and between vitamin $\mathrm{D}$ and parity were detected (Table 5). Within nulliparous cows, DCAD (positive $=1.99$ vs. negative $=1.53 \mathrm{ng} / \mathrm{mL} ; P=0.15)$ and vitamin $\mathrm{D}(\mathrm{CH}=1.61$ vs. $\mathrm{CA}=1.90 \mathrm{ng} / \mathrm{mL} ; P=0.35) \operatorname{did}$ not influence concentrations of CTX-1; however, within parous cows, those fed the diet with negative DCAD (positive $=0.90$ vs. negative $=1.22 \mathrm{ng} / \mathrm{mL} ; P=0.02$ ) 

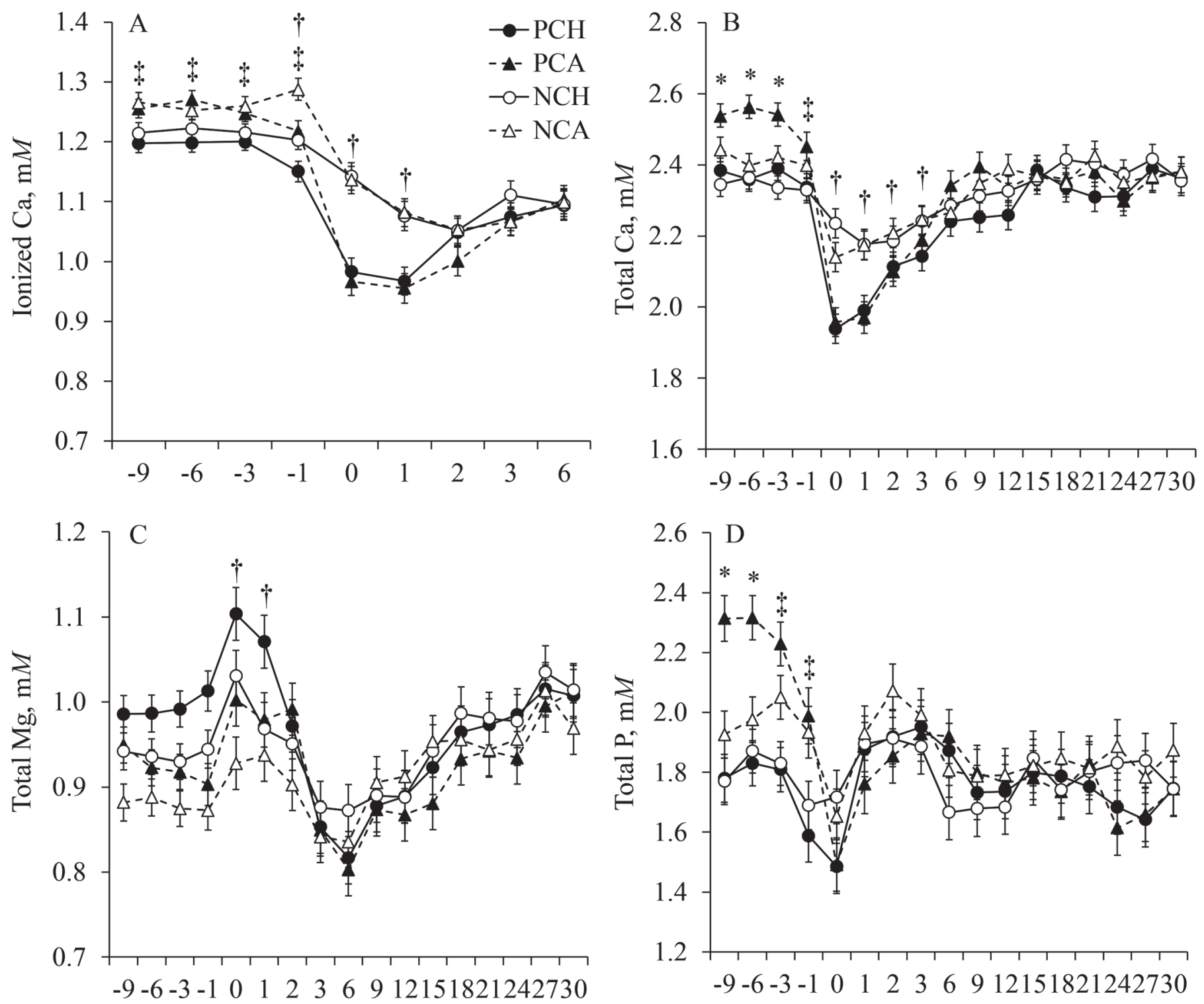

Day relative to calving

Day relative to calving

Figure 4. Concentrations of ionized $\mathrm{Ca}(\mathrm{A})$ in whole blood and total $\mathrm{Ca}(\mathrm{B}), \mathrm{Mg}(\mathrm{C})$, and $\mathrm{P}(\mathrm{D})$ in serum of cows fed prepartum diets with either positive $(\mathrm{P},+130 \mathrm{mEq} / \mathrm{kg})$ or negative $(\mathrm{N},-130 \mathrm{mEq} / \mathrm{kg}) \mathrm{DCAD}$ and containing either $3 \mathrm{mg}$ of cholecalciferol $(\mathrm{PCH}$ and $\mathrm{NCH})$ or $3 \mathrm{mg}$ of calcidiol (PCA and NCA). Within a day, $\dagger$ denotes effect of DCAD $(P<0.05)$, $\ddagger$ effect of vitamin $\mathrm{D}(P<0.05)$, and $*$ interaction between DCAD and vitamin D $(P<0.05)$. Error bars represent SEM.

or supplemented with $\mathrm{CH}(\mathrm{CH}=1.34$ vs. $\mathrm{CA}=0.81$ $\mathrm{ng} / \mathrm{mL} ; P<0.001)$ had greater concentrations than cows fed the positive DCAD or those fed CA.

Concentrations of $\mathrm{uOC}$ and $\mathrm{cOC}$ did not differ with treatment, but nulliparous cows had greater $(P<0.01)$ concentrations than parous cows for both bone metabolites (Table 5). Concentrations of cOC represented more than $90 \%$ of the total OC and were 13 - to 15 -fold greater than those of uOC; both declined $(P<0.001)$ at calving and then slightly increased in the first 3 DIM
(Figure $6 \mathrm{C}$ and $6 \mathrm{D})$. Interactions $(P=0.05)$ between DCAD and parity were observed for $\mathrm{cOC}$ and total OC because within nulliparous cows, feeding the diet with negative DCAD increased $\mathrm{cOC}$ (positive $=41.5$ vs. negative $=48.2 \mathrm{ng} / \mathrm{mL}$ ) and total $\mathrm{OC}$ (positive $=$ 44.3 vs. negative $=51.3 \mathrm{ng} / \mathrm{mL}$ ), whereas no difference was observed within parous cows for $\mathrm{cOC}$ (positive $=$ 18.2 vs. negative $=16.9 \mathrm{ng} / \mathrm{mL}$ ) and total OC (positive $=20.1$ vs. negative $=18.3 \mathrm{ng} / \mathrm{mL}$ ). The ratio of cOC to CTX-1 was used as an index of bone turnover, with in- 


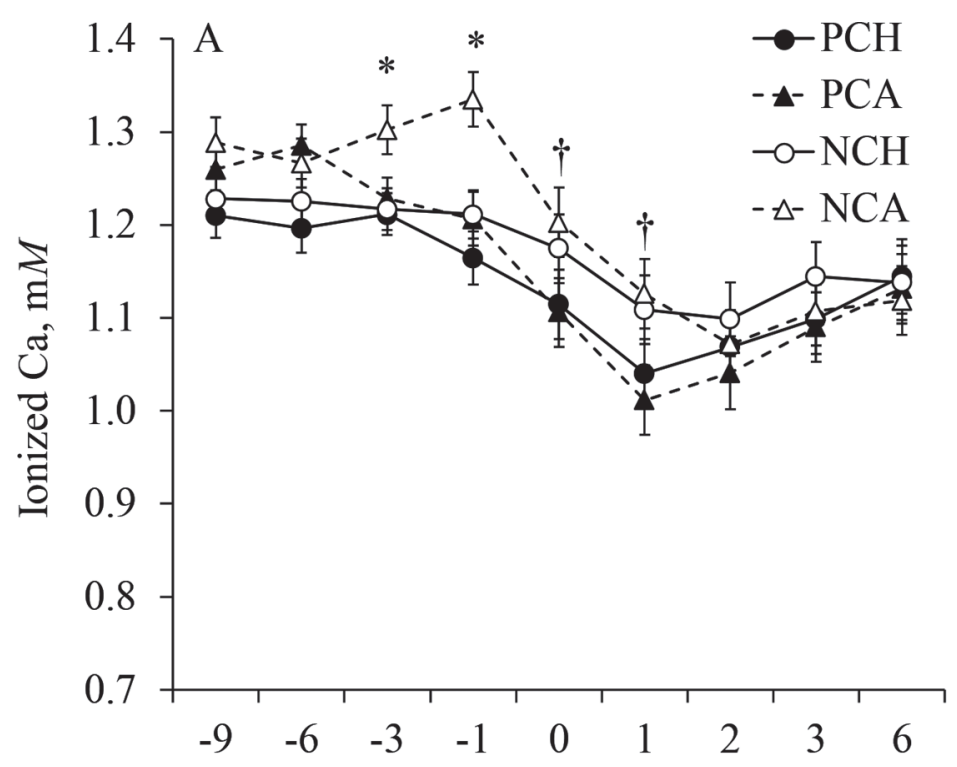

B
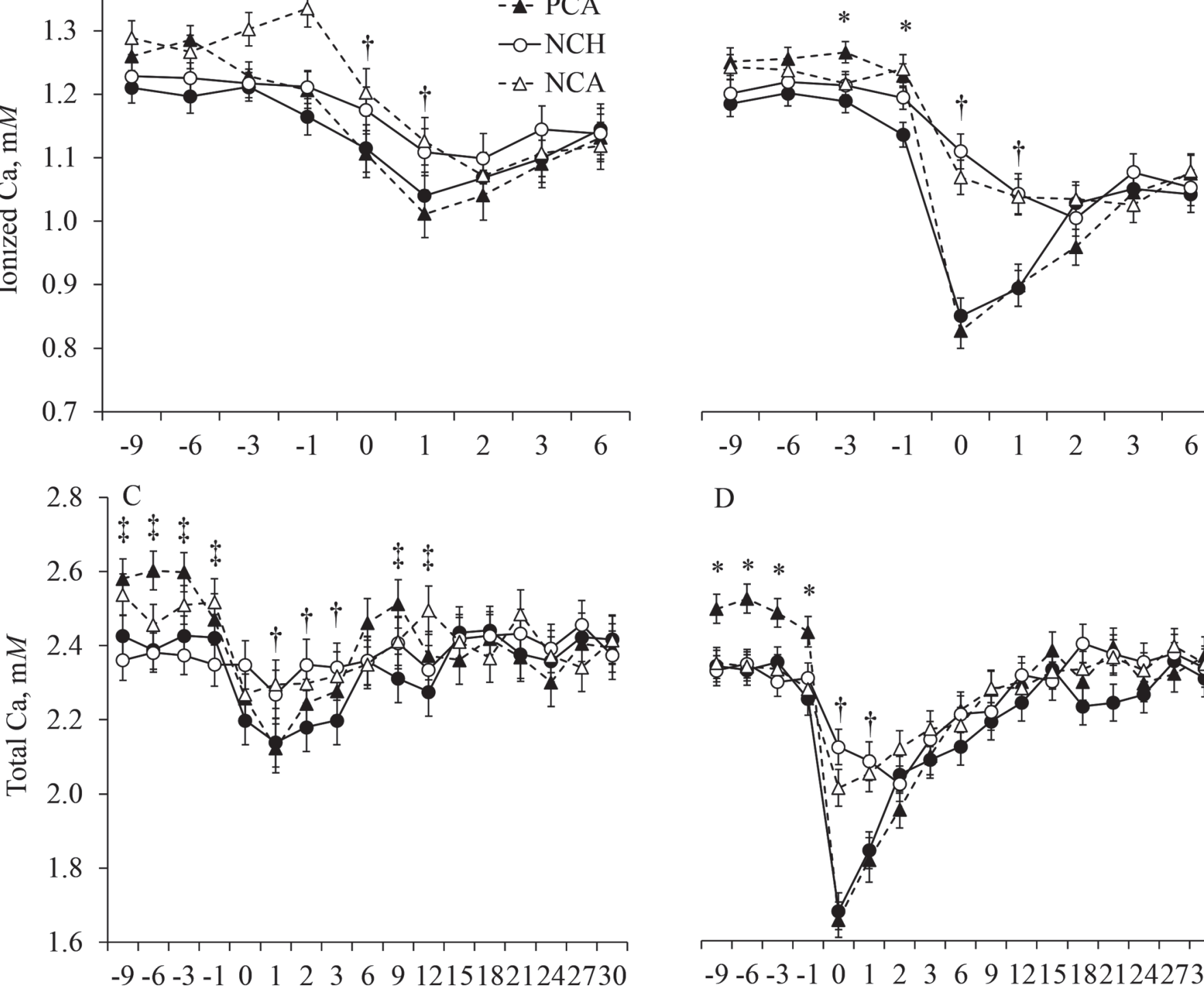

Day relative to calving

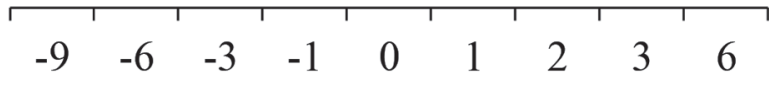

$\mathrm{D}$

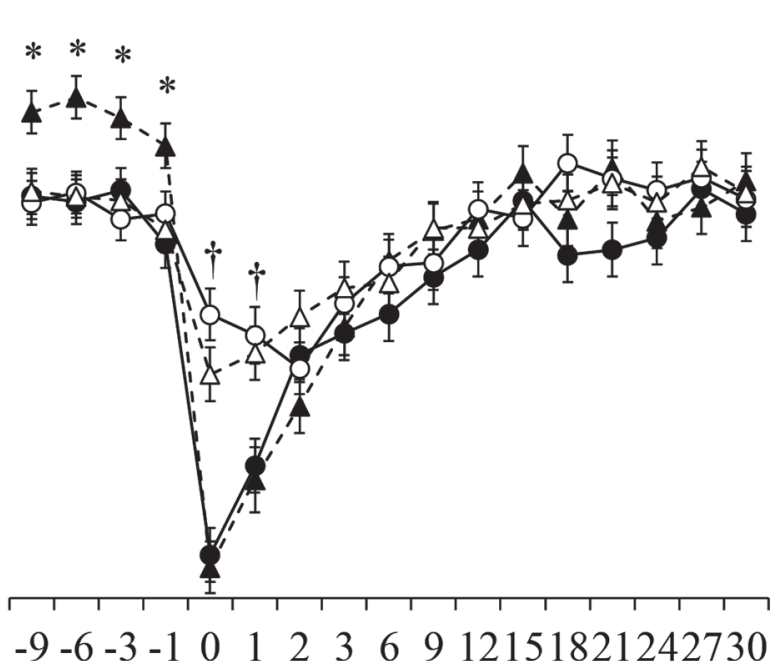

Day relative to calving

Figure 5. Concentrations of ionized $\mathrm{Ca}$ in whole blood of nulliparous (A) and parous (B) cows and total Ca in serum of nulliparous (C) and parous (D) cows fed prepartum diets with either positive $(\mathrm{P},+130 \mathrm{mEq} / \mathrm{kg})$ or negative $(\mathrm{N},-130 \mathrm{mEq} / \mathrm{kg}) \mathrm{DCAD}$ and containing either $3 \mathrm{mg}$ of cholecalciferol (PCH and $\mathrm{NCH})$ or $3 \mathrm{mg}$ of calcidiol (PCA and NCA). Within a day, $\dagger$ denotes effect of DCAD $(P<0.05)$, $\ddagger$ effect of vitamin $\mathrm{D}(P<0.05)$, and $*$ interaction between DCAD and vitamin $\mathrm{D}(P<0.05)$. Error bars represent SEM.

teractions $(P<0.05)$ between DCAD, day, and vitamin D source (Figure 7). Cows fed the diet with positive DCAD had greater $(P<0.01)$ cOC:CTX-1 ratio on the day before calving than those fed the diet with negative DCAD. Similarly, cows fed CA had a greater $(P<0.01)$ ratio on the day before calving than those fed $\mathrm{CH}$. The ratio markedly decreased $(P<0.001)$ with calving and initiation of lactation. Parity did not affect the ratio (Table 5), but interactions $(P<0.05)$ between DCAD and parity and between vitamin $D$ and parity were observed. Within nulliparous cows, DCAD did not affect the ratio, which averaged 32.8 , but feeding the diet with negative DCAD reduced $(P=0.003)$ the ratio in parous cows (positive $=37.7$ vs. negative $=$ 21.0). Also, within nulliparous, source of vitamin $\mathrm{D}$ did not influence the ratio, but feeding $\mathrm{CA}$ increased $(P<$ $0.001)$ the ratio in parous cows compared with feeding $\mathrm{CH}(\mathrm{CH}=19.7$ vs. $\mathrm{CA}=39.0)$.

Concentrations of serotonin prepartum increased $(P=0.02)$ in cows fed the diet with negative DCAD 
RODNEY ET AL.

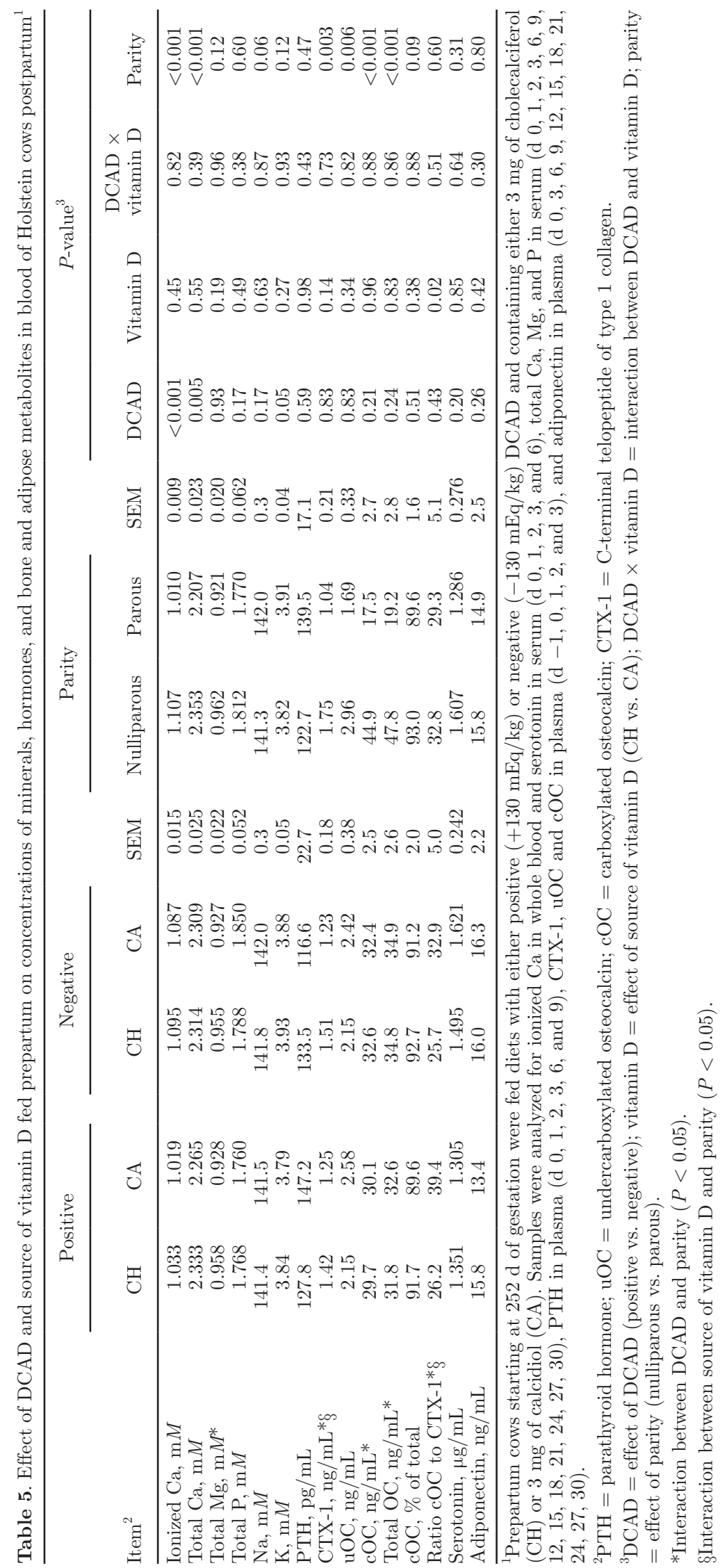



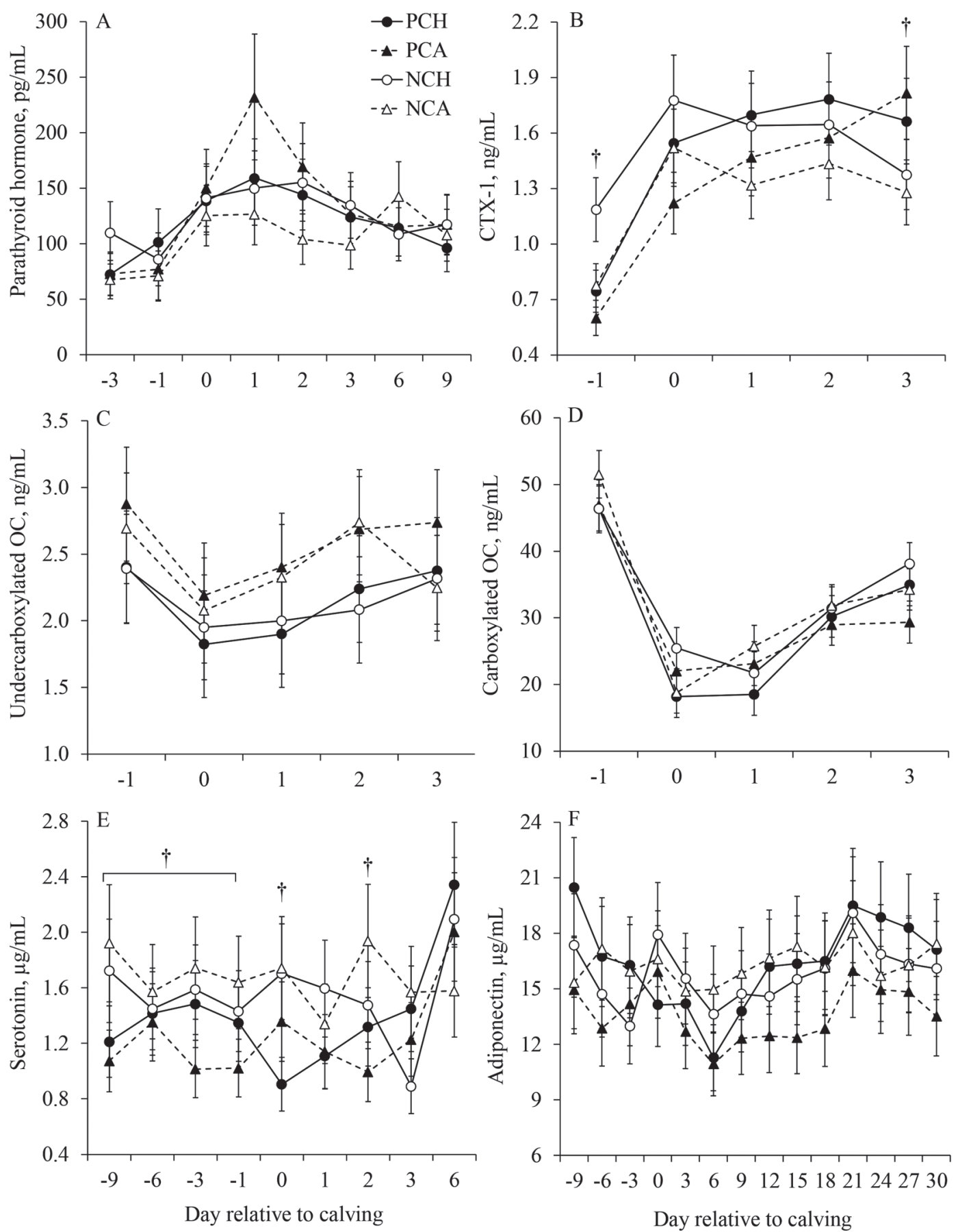

Figure 6. Concentrations of parathyroid hormone (A), C-terminal telopeptide of type 1 collagen (CTX-1; B), undercarboxylated osteocalcin ( $\mathrm{uOC}$; C), carboxylated osteocalcin (cOC), serotonin (E), and adiponectin (F) in plasma or serum of cows fed prepartum diets with either positive $(\mathrm{P},+130 \mathrm{mEq} / \mathrm{kg})$ or negative $(\mathrm{N},-130 \mathrm{mEq} / \mathrm{kg})$ DCAD and containing either $3 \mathrm{mg}$ of cholecalciferol $(\mathrm{PCH}$ and $\mathrm{NCH})$ or $3 \mathrm{mg}$ of calcidiol $(\mathrm{PCA}$ and NCA). Within a day, $\dagger$ denotes effect of DCAD $(P<0.05)$. Error bars represent SEM.

(positive $=1.327$ vs. negative $=1.557 \mu \mathrm{g} / \mathrm{mL}$; Table 4), but neither vitamin D nor the interaction between DCAD and vitamin D affected serotonin. Postpartum, an interaction $(P=0.02)$ between DCAD and day was observed because cows fed the diet with negative
DCAD had greater concentrations than those fed the positive DCAD on $\mathrm{d} 0$ and 2 postpartum (Figure $6 \mathrm{E}$ ). Nulliparous cows tended $(P=0.10)$ to have greater concentrations of serotonin prepartum than parous cows (Table 4), but this difference was no longer ob- 
served postpartum (Table 5). Treatment, parity, or the interaction between treatment and parity did not affect concentrations of adiponectin in the last $9 \mathrm{~d}$ of gestation or the first 30 DIM (Tables 4 and 5; Figure $6 \mathrm{~F})$.

\section{Acid-Base Balance}

Prepartum blood $\mathrm{pH}, \mathrm{HCO}_{3}{ }^{-}$, and base excess were all reduced $(P<0.001)$ by feeding the acidogenic diet (Table 6). Interactions $(P<0.03)$ were observed for DCAD and vitamin $\mathrm{D}$ because the reductions in $\mathrm{pH}$, $\mathrm{HCO}_{3}{ }^{-}$, and base excess were all more accentuated in cows fed CA than $\mathrm{CH}$. Tendencies for interaction $(P$ $<0.10)$ between DCAD and parity were observed for $\mathrm{HCO}_{3}{ }^{-}$and base excess because the reductions induced by feeding the diet with negative DCAD were less in nulliparous for $\mathrm{HCO}_{3}{ }^{-}$(positive $=30.5$ vs. negative $=$ $26.8 \mathrm{mM}$ ) and base excess (positive $=7.32$ vs. negative $=2.90 \mathrm{mM}$ ) than for parous cows (positive $=30.1$ vs. negative $=24.8 \mathrm{mM} ; \mathrm{HCO}_{3}{ }^{-} ;$positive $=6.66$ vs. negative $=0.54 \mathrm{~m} M$ base excess). Prepartum $\mathrm{pCO}_{2}$ was less $(P=0.01)$ for cows fed the negative than the positive DCAD diet, but treatments did not influence $\mathrm{pO}_{2}$. Cows fed negative DCAD had lower $(P<0.001)$ urinary $\mathrm{pH}$ prepartum than cows fed positive DCAD, but no differences were observed for vitamin $\mathrm{D}$.

Measures of acid-base balance postpartum were more influenced by parity than by treatments (Table 7). Blood pH did not differ among treatments, but it was higher $(P=0.004)$ for nulliparous than parous cows. Blood $\mathrm{pH}$, base excess, $\mathrm{pCO}_{2}$, and $\mathrm{pO}_{2}$ did not differ among treatments. Cows fed the positive DCAD tended $(P=0.08)$ to have lower blood $\mathrm{HCO}_{3}{ }^{-}$than cows fed the negative DCAD (positive $=32.2$ vs. negative $=$ $30.1 \mathrm{mM})$, and cows fed $\mathrm{CH}$ tended $(P=0.09)$ to have lower urinary $\mathrm{pH}$ postpartum than cows fed $\mathrm{CA}(\mathrm{CH}=$ 7.87 vs. $\mathrm{CA}=8.05)$.

\section{Urinary Excretion and Colostrum Secretion of Minerals and Estimated Mineral Balance}

Treatment did not affect concentrations of creatinine in urine pre- or postpartum (Table 8). Cows excreted an estimated 25.3 and $25.1 \mathrm{~L}$ of urine per day in the last week prepartum and in the first week of lactation, respectively. Concentration and excretion of $\mathrm{tCa}$ in the urine prepartum increased $(P<0.001)$ by feeding a diet with negative DCAD or by supplementing CA. For tMg, feeding a diet with negative DCAD reduced $(P=0.004)$ both concentration and excretion in the urine prepartum (Table 8$)$. An interaction $(P=0.03)$ between DCAD and vitamin D was detected because the reduction in urinary loss of tMg induced by feeding the negative DCAD was only observed for cows fed $\mathrm{NCH}$, not in those fed NCA. Concentrations and losses of $\mathrm{tCa}$ and $\mathrm{tMg}$ in urine in the first week postpartum did not differ with treatment. On average, pre- and postpartum, cows excreted, respectively, 7.93 and 0.49 $\mathrm{g}$ of $\mathrm{tCa} / \mathrm{d}$ and 12.14 and $6.46 \mathrm{~g}$ of $\mathrm{tMg} / \mathrm{d}$.

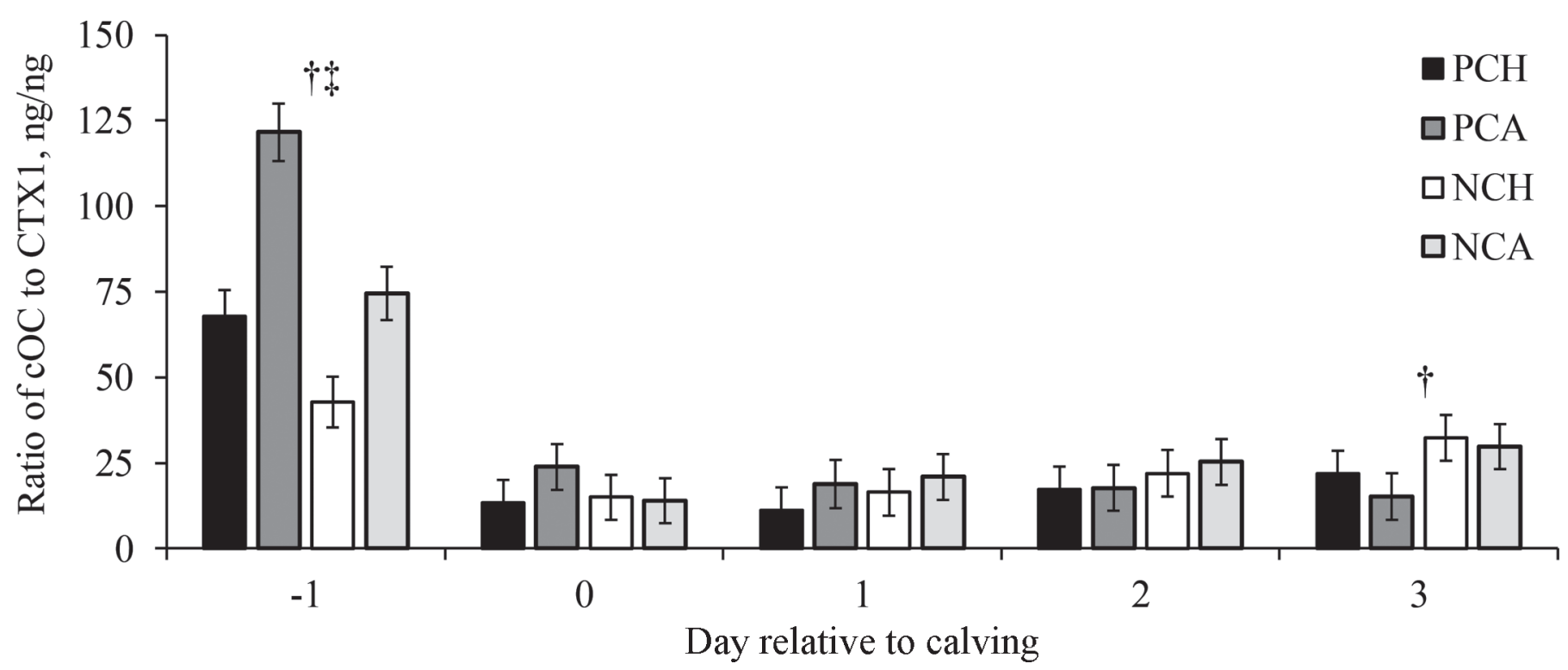

Figure 7. Ratios of carboxylated osteocalcin (cOC) to C-terminal telopeptide of type 1 collagen (CTX-1) in plasma of cows fed prepartum diets with either positive $(\mathrm{P},+130 \mathrm{mEq} / \mathrm{kg})$ or negative $(\mathrm{N},-130 \mathrm{mEq} / \mathrm{kg})$ DCAD and containing either $3 \mathrm{mg}$ of cholecalciferol (PCH and $\mathrm{NCH})$ or $3 \mathrm{mg}$ of calcidiol (PCA and NCA). Within a day, $\dagger$ denotes effect of DCAD $(P<0.05)$, $\ddagger$ effect of vitamin D $(P<0.05)$. Error bars represent SEM. 

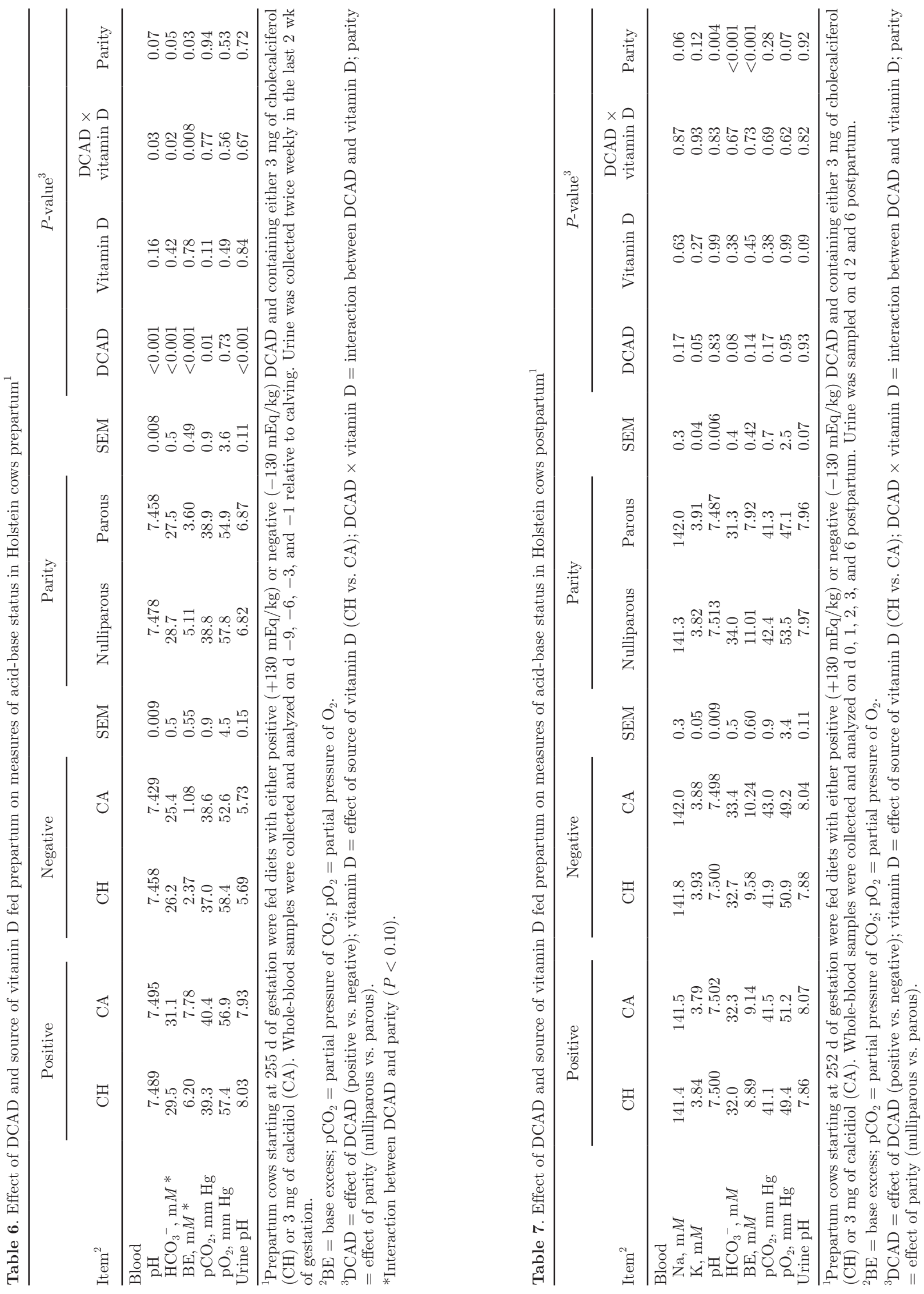
RODNEY ET AL.

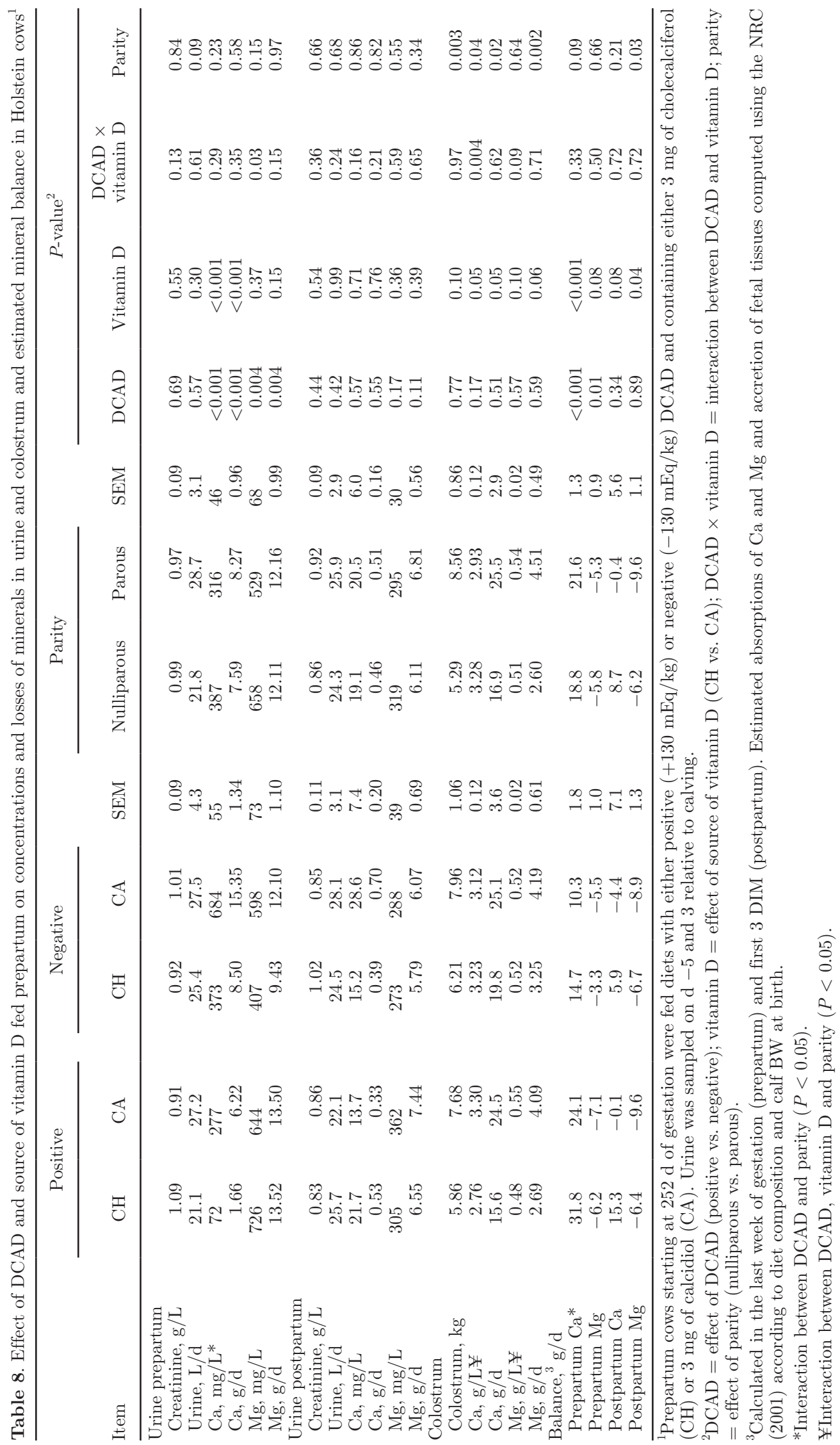


Colostrum yield did not differ between DCAD, but tended $(P=0.10)$ to be greater for cows fed CA compared with $\mathrm{CH}$. Treatment affected concentrations and loss of tCa and tMg in colostrum (Table 8). Feeding CA increased concentration of tCa in colostrum, but this effect was only observed in cows fed the diet with positive DCAD. Cows fed CA lost $7.1 \mathrm{~g}$ of additional tCa in colostrum compared with cows fed $\mathrm{CH}(\mathrm{CH}=17.7$ vs. $\mathrm{CA}=24.8 \mathrm{~g})$. An interaction $(P=0.09)$ between DCAD and vitamin D was observed for concentration of tMg in colostrum because within cows receiving the positive DCAD, those fed PCA had a greater $(P=$ 0.02 ) concentration of $\mathrm{tMg}$ than cows fed $\mathrm{PCH}$, but no difference was observed between NCH and NCA. Secretion of tMg in colostrum tended $(P=0.06)$ to increase in cows fed $\mathrm{CA}$ than in those fed $\mathrm{CH}(\mathrm{CH}=2.97$ vs. $\mathrm{CA}=4.14 \mathrm{~g})$. Colostrum yield was greater $(P=0.003)$ for parous than nulliparous, thereby increasing $(P<$ 0.02 ) the losses of tCa and $\mathrm{tMg}$ in colostrum.

The estimated balances of $\mathrm{Ca}$ and $\mathrm{Mg}$ in the last 7 $\mathrm{d}$ of gestation differed with treatment (Table 8). Cows were in positive $\mathrm{Ca}$ balance prepartum, but those fed diets with positive DCAD had greater $(P<0.001) \mathrm{Ca}$ balance than cows fed the negative DCAD (positive $=$ 28.0 vs. negative $=12.5 \mathrm{~g} / \mathrm{d}$ ), and cows fed $\mathrm{CH}$ had greater had greater $(P<0.001)$ Ca balance than cows fed $\mathrm{CA}(\mathrm{CH}=23.2$ vs. $\mathrm{CA}=17.2 \mathrm{~g} / \mathrm{d})$. Cows were in negative $\mathrm{Mg}$ balance prepartum, and it tended $(P=$ $0.08)$ to be more negative for cows fed the positive than negative DCAD (positive $=-6.7$ vs. negative $=-4.3$ $\mathrm{g} / \mathrm{d})$, and it was less negative $(P=0.01)$ for cows fed $\mathrm{CH}$ than $\mathrm{CA}(\mathrm{CH}=-4.8$ vs. $\mathrm{CA}=-6.3 \mathrm{~g} / \mathrm{d})$. Calcium balance decreased $(P<0.001)$ with the onset of lactation from 20.3 to $4.2 \mathrm{~g} / \mathrm{d}$ and it tended $(P=0.08)$ to be greater for $\mathrm{CH}$ than $\mathrm{CA}(\mathrm{CH}=10.6$ vs. $\mathrm{CA}=-2.3$ $\mathrm{g} / \mathrm{d}$ ), but it was not affected by DCAD. Only $1 \mathrm{NCH}$ cow was in negative $\mathrm{Ca}$ balance prepartum, whereas postpartum proportions of cows with negative Ca balance were $29.4 \%$ for $\mathrm{PCH}, 47.4 \%$ for $\mathrm{PCA}, 36.8 \%$ for $\mathrm{NCH}$, and $55.0 \%$ for NCA. Magnesium balance became more $(P=0.002)$ negative postpartum, from $-5.5 \mathrm{~g} / \mathrm{d}$ prepartum to $-7.9 \mathrm{~g} / \mathrm{d}$ with the onset of lactation. Altering the DCAD did not influence postpartum $\mathrm{Mg}$ balance, but feeding $\mathrm{CA}$ further reduced $\mathrm{Mg}$ balance compared with $\mathrm{CH}(\mathrm{CH}=-6.5$ vs. $\mathrm{CA}=-9.2 \mathrm{~g} / \mathrm{d})$.

\section{DISCUSSION}

Supplementing CA in place of $\mathrm{CH}$ during the last $3 \mathrm{wk}$ of gestation was superior in increasing plasma concentrations of vitamin D metabolites pre- and postpartum and concentrations of minerals in whole blood and plasma prepartum in dairy cows. Concurrent with the changes observed with sources of vitamin $\mathrm{D}$, feed- ing a diet with negative DCAD prepartum induced a compensated metabolic acidosis in dairy cows, which attenuated the decline in blood iCa and serum tCa after parturition, with effects more pronounced in parous than nulliparous cows.

Vitamin D metabolism plays critical roles in mineral homeostasis, particularly Ca metabolism. 25-Hydroxyvitamin $\mathrm{D}_{3}$ is the standard vitamin $\mathrm{D}$ quantified to determine adequacy because it is the predominant metabolite found in plasma and has a long half-life (Jones, 2008). Concentrations considered adequate suggested by Horst et al. (1994) range from 20 to 50 $\mathrm{ng} / \mathrm{mL}$, although the minimum concentration of 25-hydroxyvitamin $\mathrm{D}_{3}$ that optimizes mineral metabolism and health of dairy cattle has not been defined. Nelson et al. (2012) suggested a minimum of $30 \mathrm{ng} / \mathrm{mL}$ for proper immune function. A recent survey of 12 dairy herds in the United States demonstrated that the mean $( \pm \mathrm{SD})$ concentration of 25-hydroxyvitamin $\mathrm{D}_{3}$ in lactating dairy cows sampled at all stages of lactation was $68 \pm 22 \mathrm{ng} / \mathrm{mL}$ (Nelson et al., 2016). Unsurprisingly, feeding cows CA increased plasma concentrations of 25-hydroxyvitamin $\mathrm{D}_{3}$ to values much larger than in those fed $\mathrm{CH}$, and concentrations remained elevated past the last day of supplementation. Even within cows fed $\mathrm{CH}$, concentrations of 25-hydroxyvitamin $\mathrm{D}_{3}$ in plasma increased with day of supplementation, despite the decline in DM and $\mathrm{CH}$ intakes as calving approached (Martinez et al., 2018a), which likely reflect the natural conversion of vitamin $\mathrm{D}_{3}$ to 25 -hydroxyvitamin $\mathrm{D}_{3}$ (Ponchon et al., 1969). Concentrations of vitamin $\mathrm{D}_{3}$ in plasma increased only in cows fed $\mathrm{CH}$, although those fed CA had concentrations prepartum within what has been suggested as the normal range in cattle, 1 to $3 \mathrm{ng} /$ $\mathrm{mL}$ (Horst et al., 1981).

It is interesting that concentrations of 25-hydroxyvitamin $\mathrm{D}_{3}$ in plasma of individual cows fed $3 \mathrm{mg}$ of $\mathrm{CH}$ did not exceed $90 \mathrm{ng} / \mathrm{mL}$, suggesting some limit in the conversion of dietary vitamin $\mathrm{D}_{3}$ into plasma 25-hydroxyvitamin $\mathrm{D}_{3}$ in dairy cows. Horst and Reinhardt (1983) injected 2 cows with $375 \mathrm{mg}$ of cholecalciferol each and showed that plasma concentrations of vitamin $\mathrm{D}_{3}$ increased to almost $50 \mathrm{ng} / \mathrm{mL}$, approximately 3 -fold greater than the values observed for $\mathrm{PCH}$ cows prepartum. Despite the massive increase in vitamin $\mathrm{D}_{3}$, plasma concentrations of 25-hydroxyvitamin $\mathrm{D}_{3}$ remained below $100 \mathrm{ng} / \mathrm{mL}$ in the subsequent $77 \mathrm{~d}$ (Horst and Reinhardt, 1983). Nelson et al. (2016) reported that lactating cows supplemented with 0.75 to $1.25 \mathrm{mg}$ of vitamin $\mathrm{D}_{3}$ had 25-hydroxyvitamin $\mathrm{D}_{3}$ concentrations between 42 and $96 \mathrm{ng} / \mathrm{mL}$ (10th and 90th percentiles). In the current study, no cow fed $\mathrm{CH}$, in which vitamin $\mathrm{D}_{3}$ was supplemented at $3 \mathrm{mg} / \mathrm{d}$, had a concentration of 25-hydroxyvitamin $\mathrm{D}_{3}$ in plasma $>90 \mathrm{ng} / \mathrm{mL}$, either 
during supplementation in the prepartum period or postpartum. Poindexter (2017) showed that increasing intake of vitamin $\mathrm{D}_{3}$ from 1 to $3 \mathrm{mg} / \mathrm{d}$ for $28 \mathrm{~d}$ did not increase concentrations of 25-hydroxyvitamin $\mathrm{D}_{3}$ in plasma of lactating dairy cows, and concentrations in individual cows did not surpass $90 \mathrm{ng} / \mathrm{mL}$; however, feeding $3 \mathrm{mg} / \mathrm{d}$ of cholecalciferol doubled vitamin $\mathrm{D}_{3}$ concentrations in serum compared with feeding $1 \mathrm{mg} / \mathrm{d}$. Conversion of vitamin $\mathrm{D}_{3}$ into 25-hydroxyvitamin $\mathrm{D}_{3}$ by 25-hydroxylase was first identified in the liver in rats almost 50 yr ago (Ponchon et al., 1969); however, little is known about the regulation of this enzyme in bovine liver. Two forms of 25-hydroxylase have been identified, a mitochondrial and a microsomal enzyme, and serum concentrations of 25-hydroxyvitamin $\mathrm{D}_{3}$ have been correlated with mitochondrial 25-hydroxylase activity in the liver of rats (Dahlbäck and Wikvall, 1987). In cattle, mutations in the CYPQJ2 gene are associated with concentrations of 25-hydroxyvitamin $\mathrm{D}_{3}$ in serum (Casas et al., 2013), but, in general, vitamin D 25-hydroxylase activity is considered an unregulated step in the vitamin $\mathrm{D}$ pathway. It is possible that bovine 25-hydroxylase activity is saturated by a large supply of vitamin $\mathrm{D}_{3}$ or that other compounds of vitamin D metabolism control expression and activity of 25-hydroxylase such that conversion of vitamin $\mathrm{D}_{3}$ into 25 -hydroxyvitamin $\mathrm{D}_{3}$ is inhibited. Some evidence suggests that 25-hydroxylase activity is influenced by 1,25-dihydroxyvitamin $\mathrm{D}_{3}$ (Baran and Milne, 1986), and this effect might be mediated by cytosolic concentrations of iCa (Baran and Milne, 1986; Corlett et al., 1987).

Feeding the acidogenic diet reduced concentrations of both vitamin $\mathrm{D}_{3}$ and 25-hydroxyvitamin $\mathrm{D}_{3}$ in plasma of dairy cows. Because cows were supplemented with $3 \mathrm{mg}$ of $\mathrm{CH}$ or $\mathrm{CA}$ for each $11 \mathrm{~kg}$ of DM, differences in DMI would influence the total intake of vitamin D supplements. Cows fed the negative DCAD diet consumed less DM prepartum than cows fed the positive DCAD diet (Martinez et al., 2018a). This effect was only observed in parous cows (positive DCAD $=13.7$ vs. negative $\mathrm{DCAD}=11.5 \mathrm{~kg} / \mathrm{d}$ ), and not in nulliparous cows (positive $=11.0$ vs. negative $=11.3 \mathrm{~kg} / \mathrm{d}$ ). The reduced intake of $\mathrm{DM}$ in parous cows fed $\mathrm{NCH}$ and NCA could reduce concentrations of vitamin $\mathrm{D}_{3}$ and 25-hydroxyvitamin $\mathrm{D}_{3}$ in plasma; however, the lack of interaction between DCAD and parity on concentrations of vitamin $\mathrm{D}_{3}$ and 25-hydroxyvitamin $\mathrm{D}_{3}$ indicates that the reduced concentrations caused by feeding the diet with negative DCAD was not solely mediated by lesser intake of DM. Because nulliparous cows fed the diet with negative DCAD had the same DMI and, consequently, the same supplemental vitamin $\mathrm{D}$ intake as those fed the positive DCAD, differences in plasma concentrations cannot be attributed to supply of the vitamin as in parous cows. Specifically, in nulliparous cows prepartum, the concentrations of vitamin $\mathrm{D}_{3}$ in plasma decreased from $5.12 \mathrm{ng} / \mathrm{mL}$ in positive DCAD to $3.87 \mathrm{ng} / \mathrm{mL}$ in negative DCAD, and those of 25-hydroxyvitamin $\mathrm{D}_{3}$ decreased from $160.7 \mathrm{ng} / \mathrm{mL}$ in positive DCAD to $131.9 \mathrm{ng} / \mathrm{mL}$ in negative DCAD, representing reductions in plasma concentrations of 18 to $24 \%$, although intake did not differ. These data suggest that the metabolic acidosis induced by diets with negative DCAD might influence absorption or postabsorptive metabolism of vitamin D compounds provided in the diet.

Weiss et al. (2015) fed Holstein cows diets prepartum with either positive $(+165 \mathrm{mEq} / \mathrm{kg})$ or negative $(-139$ $\mathrm{mEq} / \mathrm{kg})$ DCAD and supplemented with $0.45 \mathrm{mg}$ of vitamin $\mathrm{D}_{3}$. Feeding the diet with negative DCAD only numerically reduced concentrations of 25-hydroxyvitamin $\mathrm{D}_{3}$, but differences in 25-hydroxyvitamin $\mathrm{D}_{3}$ concentrations between cows fed positive and negative DCAD increased with days in the experiment, suggesting a possible effect of DCAD on endogenous synthesis or catabolism of 25-hydroxyvitamin $\mathrm{D}_{3}$. A metabolic acidosis induced by acidogenic diets increases blood iCa concentrations around calving in dairy cows (Charbonneau et al., 2006), which might affect subsequent release of PTH and thus the activity of 1- $\alpha$-hydroxylase responsible for production of 1,25-dihydroxyvitamin $\mathrm{D}_{3}$ (Fraser and Kodicek, 1970). Feeding acidogenic diets increased blood concentrations of 1,25-dihydroxyvitamin $\mathrm{D}_{3}$ and tCa in response to exogenous PTH (Goff et al., 2014). Nevertheless, we are not aware of data demonstrating effects of acidogenic diets on absorption and concentrations of vitamin $\mathrm{D}_{3}$ or on conversion of vitamin $\mathrm{D}_{3}$ into 25-hydroxyvitamin $\mathrm{D}_{3}$ in dairy cattle.

Concentrations of 25-hydroxyvitamin $\mathrm{D}_{2}$ and 3-epi 25-hydroxyvitamin $\mathrm{D}_{3}$ were affected by treatment. Vitamin $\mathrm{D}_{2}$ is produced by UV irradiation of ergosterol from fungi and is expected to be present in relatively low but consistent concentrations in forages fed to dairy cows (Wallis et al., 1958), including those in the present experiment. Vitamin $\mathrm{D}_{2}$ is hydroxylated in the liver by the microsomal 25-hydroxylase to 25-hydroxyvitamin $\mathrm{D}_{2}$ (Bikle, 2014), and later catabolized by the 24-hydroxylase (Horst et al., 1986). It is unclear why cows fed NCA had a $27 \%$ increase in concentrations of 25-hydroxyvitamin $\mathrm{D}_{2}$ throughout the experiment compared with cows fed the other 3 diets. 3-Epi 25-hydroxyvitamin $\mathrm{D}_{3}$ is synthesized by a 3-epimerase and it has identical molecular structure to 25-hydroxyvitamin $\mathrm{D}_{3}$, but they differ in stereochemical configuration (Bikle, 2014). The biological function of 3-epi 25-hydroxyvitamin $\mathrm{D}_{3}$ is poorly described and we are unaware of dietary or metabolic factors that influence synthesis and metabolism of this vitamin D metabolite 
in cattle. Rodney et al. (2018) showed a linear increase in 3-epi 25-hydroxyvitamin $\mathrm{D}_{3}$ but a quadratic decrease in 25-hydroxyvitamin $\mathrm{D}_{2}$ concentrations in plasma of mid-lactation dairy cows supplemented with $0,0.5$, 1,2 , or $4 \mathrm{mg} / \mathrm{d}$ of calcidiol. Their data demonstrated that both metabolites are influenced by the supply of dietary calcidiol.

The conversion of 25-hydroxyvitamin $\mathrm{D}_{3}$ into 1,25-dihydroxyvitamin $\mathrm{D}_{3}$ is known to occur in response to metabolic demand independently of substrate availability; however, the results of this experiment show that concentrations of 1,25-dihydroxyvitamin $\mathrm{D}_{3}$ can increase by feeding high doses of CA to dairy cows. The increased 1,25-dihydroxyvitamin $\mathrm{D}_{3}$ concentration prepartum in cows fed $\mathrm{CA}$ might indicate that supplying large doses of 25-hydroxyvitamin $\mathrm{D}_{3}$ might override the regulatory mechanisms for synthesis of 1,25-dihydroxyvitamin $\mathrm{D}_{3}$. At 1 and 2 DIM, 1,25-dihydroxyvitamin $\mathrm{D}_{3}$ was highest in cows fed $\mathrm{PCH}$, likely because those cows had reduced concentrations of iCa compared with cows fed $\mathrm{NCH}$ or NCA.

The increase in 1,25-dihydroxyvitamin $\mathrm{D}_{3}$ with feeding $\mathrm{CA}$ was minor compared with the massive increase in concentrations of the inactive metabolite 24,25-dihydroxyvitamin $\mathrm{D}_{3}$. The increase in 24,25-dihydroxyvitamin $\mathrm{D}_{3}$ above typically reported values of $2.6 \pm 1.3$ $\mathrm{ng} / \mathrm{mL}$ (Horst et al., 1981), which was observed in cows fed CA, is likely the result of increased supply of 25-hydroxyvitamin $\mathrm{D}_{3}$ as substrate for the cytochrome P450 enzyme 24-hydroxylase. A linear relationship was observed between 25-hydroxyvitamin $\mathrm{D}_{3}$ and 24,25-dihydroxyvitamin $\mathrm{D}_{3}$ concentrations in plasma in cows fed $\mathrm{CH}$ and $\mathrm{CA}$, reinforcing the concept that supply of substrate increases the side-chain hydroxylation to convert 25-hydroxyvitamin $\mathrm{D}_{3}$ and 1,25-dihydroxyvitamin $\mathrm{D}_{3}$ into inactive 24-hydroxylated vitamin $\mathrm{D}_{3}$ metabolites. In fact, the ratio of 24,25 -dihydroxyvitamin $\mathrm{D}_{3}$ to 25-hydroxyvitamin $\mathrm{D}_{3}$ increased 3 -fold pre- and postpartum in cows fed CA compared with cows fed $\mathrm{CH}$, supporting the concept of induction of 24-hydroxylase abundance or activity as the supply of 25 -hydroxyvitamin $\mathrm{D}_{3}$ increased. Abundance of the 24-hydroxylase enzyme increases by 1,25-dihydroxyvitamin $\mathrm{D}_{3}$ via vitamin $\mathrm{D}$ response elements in the CYP24A1 gene promoter (Pike, 2011), and administration of 1,25-dihydroxyvitamin $\mathrm{D}_{3}$ to cows immediately after calving increased concentrations of 24,25-dihydroxyvitamin $\mathrm{D}_{3}$ (VieiraNeto et al., 2017); thus, increased 24,25-dihydroxyvitamin $\mathrm{D}_{3}$ concentrations in calcidiol-fed cows may also be caused by increased 24-hydroxylase abundance. Differences in concentrations of 24,25-dihydroxyvitamin $\mathrm{D}_{3}$ between parity groups suggest that as cows age, activity of 24-hydroxylase increases, perhaps because of uncoupling $C Y$ P2 $_{4} A 1$ with age that might contribute to the impairment of vitamin $\mathrm{D}$ metabolism that has been shown in old dairy cows (Horst et al., 1990). The side-chain hydroxylation of 25-dihydroxyvitamin $\mathrm{D}_{3}$ and 1,25-dihydroxyvitamin $\mathrm{D}_{3}$ makes the 2 vitamin $\mathrm{D}$ metabolites more easily removed from circulation and is a key process in preventing excess accumulation of vitamin D metabolites (Horst et al., 1994). The finding that cows fed the diet with positive DCAD also had greater concentrations of 24,25-dihydroxyvitamin $\mathrm{D}_{3}$ compared with those fed the negative DCAD diet likely reflects the increased concentrations of 25-hydroxyvitamin $\mathrm{D}_{3}$ in cows fed the positive DCAD.

Feeding CA increased concentrations of tCa and $\mathrm{tP}$ prepartum but not postpartum, indicating that increasing concentrations of 25 -hydroxyvitamin $\mathrm{D}_{3}$ by feeding CA with either positive or negative DCAD is not effective in minimizing postpartum hypocalcemia. Furthermore, cows fed PCA had the smallest concentrations of Ca postpartum, indicating a potential negative consequence to high concentrations of 25-hydroxyvitamin $\mathrm{D}_{3}$ if DCAD is not manipulated to minimize postpartum Ca loss. Wilkens et al. (2012) observed similar responses when cows were fed calcidiol at $3 \mathrm{mg} / \mathrm{d}$, and Weiss et al. (2015) observed increased concentrations of tCa prepartum, but no effect on postpartum tCa by feeding cows $6 \mathrm{mg} / \mathrm{d}$ of calcidiol prepartum. The inability of CA to improve postpartum $\mathrm{Ca}$ in the current study likely stems from greater disruption of $\mathrm{Ca}$ and $\mathrm{P}$ homeostasis and vitamin $\mathrm{D}$ metabolism in cows fed CA. Feeding CA increased the loss of minerals in urine and colostrum, particularly tCa, by approximately 13 $\mathrm{g} / \mathrm{d}$, which probably contributed to low serum tCa and blood iCa following calving when cows were fed PCA. On the other hand, when cows were fed NCA, despite increased losses of tCa in colostrum and urine, those cows maintained increased concentrations of tCa and $\mathrm{iCa}$ in blood in the first days of lactation. Because CA tended to increase colostrum yield, the loss of both $\mathrm{tCa}$ and $\mathrm{tMg}$ was expected to increase. In addition, within cows fed the diet with positive DCAD, those supplemented with CA had increased concentrations of both tCa and $\mathrm{tMg}$ in colostrum. Such a loss of tCa is anticipated to influence $\mathrm{Ca}$ homeostasis and the ability to maintain normocalcemia at the onset of lactation. This became important particularly when cows were fed the diet with positive DCAD because it is known that under alkalosis, 1,25-hydroxyvitamin $\mathrm{D}_{3}$ synthesis in response to PTH and control of blood $\mathrm{iCa}$ and tCa is compromised (Charbonneau et al., 2006; Lean et al., 2006; Goff et al., 2014).

Wilkens et al. (2012) observed that supplementing calcidiol to a prepartum diet with positive DCAD resulted in the lowest blood $\mathrm{iCa}$ in cows of third or greater lactations, which are the most susceptible to 
milk fever (Lean et al., 2006). Feeding PCA resulted in the highest concentrations of serum tP prepartum, as observed by Wilkens et al. (2012), and increased tP in plasma is known to stimulate production and secretion of fibroblast growth factor (FGF) 23 by osteoblasts and osteocytes, which regulates blood phosphate, but also inhibits $1 \alpha$-hydroxylase, thereby suppressing the synthesis of 1,25-dihydroxyvitamin $\mathrm{D}_{3}$ (Bikle, 2014). Also, FGF23 stimulates the catabolism of 25-hydroxyvitamin $\mathrm{D}_{3}$ and 1,25-dihydroxyvitamin $\mathrm{D}_{3}$ by activating renal 24-hydroxylase (Bikle, 2014), thereby increasing the conversion into 24,25-dihydroxyvitamin $\mathrm{D}_{3}$. Cows fed PCA had the greatest pre- and postpartum concentrations of 24,25-dihydroxyvitamin $\mathrm{D}_{3}$ and the largest ratio of 24,25-dihydroxyvitamin $\mathrm{D}_{3}$ to 25 -hydroxyvitamin $\mathrm{D}_{3}$.

The onset of lactation and associated increase in demand for Ca triggered a marked, but expected, decrease in blood $\mathrm{iCa}$ and $\mathrm{tCa}$ concentrations in all treatments. Nevertheless, this decrease was less apparent in cows fed the acidogenic diet, which attenuated the decline in $\mathrm{iCa}$ and tCa, particularly in parous cows. The relatively more stable Ca concentrations in cows fed the diet with negative DCAD contributed to the reductions in the incidence of both clinical and subclinical hypocalcemia reported in the companion paper (Martinez et al., 2018b). Feeding the diet with negative DCAD induced a typical compensated metabolic acidosis in cows in the prepartum period with reductions in blood and urinary $\mathrm{pH}$ and in concentrations of $\mathrm{HCO}_{3}{ }^{-}$, base excess, and $\mathrm{pCO}_{2}$ in whole blood. Most of those responses were no longer detected in the first 6 DIM, which reflects the similar and alkalogenic diet fed upon calving to all cows. The acid-base responses to feeding acidogenic diets prepartum have been well documented in the literature (Charbonneau et al., 2006), and metabolic acidosis has been shown to promote response to PTH in dairy cows (Goff et al., 2014), which explains the benefits to Ca homeostasis and the resulting increments in urinary mineral losses.

One of the goals of this experiment was to identify integration of vitamin $\mathrm{D}$, mineral, and bone metabolism as the cow transitions into lactation that would be reflected into subsequent benefits to health and lactation (Lean et al., 2014; Martinez et al., 2018a). Feeding the diet with negative DCAD increased concentrations of serotonin prepartum. Serotonin plays a role in bone remodeling as it is required for osteoclastogenesis (Chabbi-Achengli et al., 2012), and it regulates $\mathrm{Ca}$ transport into mammary epithelial cells during lactation (Laporta et al., 2014a). In response to lactation, serotonin produced by the mammary gland triggers production of PTH-related protein that stimulates osteoclast activity and increased bone mobilization (Laporta et al., 2014b). Because DCAD was shown to influence serotonin as cows approached calving, and treatment with 1,25-dihydroxyvitamin $\mathrm{D}_{3}$ immediately after calving has been shown to increase serotonin in dairy cows (Vieira-Neto et al., 2017), it is clear that these dietary interventions can influence endocrine signals that affect nutrient flux to the mammary gland.

Integration of bone and energy metabolism has been proposed in murine and human studies (Lee et al., 2007; Wolf, 2008) and more recently in cattle (Lean et al., 2014). Lee et al. (2007) showed that transgenic mice lacking osteocalcin had reduced pancreatic $\beta$-cell proliferation, glucose intolerance, and insulin resistance, suggesting crosstalk between osteoblast-secreted molecules and control of energy metabolism. Numerous other experiments have shown that molecules derived from skeleton to influence energy metabolism, and molecules produced by adipocytes can affect bone formation (Wolf, 2008). Although the treatments imposed in the current experiment had remarkable influences on vitamin $\mathrm{D}$ and mineral metabolism, affected aspects of energy metabolism with enhanced yields of milk and milk components (Martinez et al., 2018a), and reduced the incidence of health disorders (Martinez et al., 2018b), the direct interplay between bone-secreted molecules and energy metabolism was not evident.

Concentrations of $\mathrm{uOC}$ and $\mathrm{cOC}$ did not differ with treatments, except for an increase in nulliparous cows fed the negative DCAD diet. Osteocalcin is an osteoblast-derived protein present at high concentration in the bone extracellular matrix that undergoes a posttranslational vitamin $\mathrm{K}$-dependent $\gamma$-carboxylation that converts glutamic acid residues to $\gamma$-carboxyglutamic acid in the molecule, which increases affinity for $\mathrm{Ca}$ and hydroxyapatite in bones (Wolf, 2008). It has been identified in bovines (Price et al., 1976) and was shown to be released into the bloodstream by osteoblasts as new bone is formed; however, uOC plays major roles in energy metabolism influencing insulin release and glucose homeostasis (Lee et al., 2007). More than $90 \%$ of OC identified in blood plasma in the present experiment was cOC. That only cOC was affected by negative DCAD in nulliparous cows might suggest that the manipulations imposed affected bone metabolism, but the changes in energy metabolism might not be mediated by bone in transition cows. Also, treatments did not affect the concentrations of adiponectin reported herein and those of leptin and insulin reported by Martinez et al. (2018a). Although differences in bone markers with treatment were minor, CTX-1 increased prepartum in cows fed the diet with negative DCAD, but marked differences were observed with parity; nulliparous had greater concentrations of $\mathrm{uOC}, \mathrm{cOC}$, and CTX-1 and tended to have a larger portion of the total $\mathrm{OC}$ as cOC than parous cows. The differences between 
parity groups are not surprising for bone-related markers because nulliparous animals are growing, accreting, and remodeling bone to a greater extent than older cows (Sato et al., 2011) and are better able to cope with the demands for $\mathrm{Ca}$ with the onset of lactation (Lean et al., 2006).

The ratio cOC:CTX-1 was used as an index of bone turnover (Wilkens et al., 2014), and an increase in the ratio suggests increments in bone accretion relative to resorption, whereas a reduction suggests a decrease in bone accretion relative to resorption. As expected, dynamic changes were observed as cows calved and lactation initiated, with a marked reduction in the ratio starting on the day of calving, likely to support the irreversible losses of $\mathrm{Ca}$ in colostrum and milk. In fact, secretion of colostrum and milk caused $42.7 \%$ of the cows to be in negative $\mathrm{Ca}$ balance, which agrees with balance studies showing positive $\mathrm{Ca}$ balance prepartum, but negative in the first week of lactation (Ender et al., 1971). Similar to our findings, Wilkens et al. (2014) documented a marked decline in the ratio of OC to CTX-1 in dairy goats as they transition from the dry period into lactation. Effects of treatment were observed primarily before calving, and CA increased the ratio, suggesting increased bone accretion relative to resorption, whereas feeding a diet with negative DCAD reduced the ratio, suggesting improved bone resorption with acidogenic compared with alkalogenic diets. Parous cows were responsive to the effects of DCAD or vitamin $\mathrm{D}$ affecting the ratio of $\mathrm{cOC}$ to $\mathrm{CTX}-1$, perhaps because the demands for $\mathrm{Ca}$ are greater or because the effect of vitamin $\mathrm{D}$ on intestinal cells stimulating $\mathrm{Ca}$ absorption diminishes with age (Horst et al., 1990), thereby making the animal more dependent on bone turnover to meet the sudden needs for $\mathrm{Ca}$ with the onset of lactation.

Supplementing cholecalciferol or calcidiol as a large single bolus dose of $15 \mathrm{mg}$ did not affect concentrations of total OC in cows (Taylor et al., 2008). On the other hand, a subcutaneous or intramuscular injection of $0.5 \mu \mathrm{g}$ of calcitriol $/ \mathrm{kg}$ of $\mathrm{BW}$ in nonlactating cows elevated plasma concentrations of OC over several days after treatment (Kim et al., 2011). Treatment with calcitriol induced a rapid increase of blood $\mathrm{iCa}$ and tCa, within approximately 12 to $24 \mathrm{~h}$ but it did not seem to alter markers of bone resorption (Kim et al., 2011; Vieira-Neto et al., 2017). Nevertheless, injectable calcitriol increased concentrations of cOC in nonpregnant, nonlactating cows (Kim et al., 2011), which differ considerably in metabolism from periparturient cows. Positive associations between plasma 25-hydroxyvitamin $\mathrm{D}_{3}$ and $\mathrm{OC}$ concentrations were identified in mid-lactation dairy cows using time-series statistical methods (Rodney et al., 2018), suggesting potential associations between the 2 molecules. At this point, it remains unclear whether the treatments implemented to alter vitamin $\mathrm{D}$ and mineral metabolism are capable of influencing bone markers that cross-talk with other endocrine signals such as adiponectin, leptin, and insulin in transition dairy cows.

\section{CONCLUSIONS}

Supplementing diets of prepartum cows with $3 \mathrm{mg}$ of CA increased concentrations of vitamin D metabolites in plasma throughout the transition period compared with the same amount of $\mathrm{CH}$. Concurrently, feeding an acidogenic diet prepartum induced a compensated metabolic acidosis that attenuated the decline in iCa and tCa with the onset of lactation. Calcidiol increased prepartum concentrations of $\mathrm{iCa}, \mathrm{tCa}$, and tP but decreased those of $\mathrm{tMg}$, which resulted in increased urinary excretion of tCa but not that of $\mathrm{tMg}$. On the other hand, feeding a diet with negative DCAD increased excretion of tCa and tMg in urine, particularly when fed concurrently with CA. Because CA tended to increase colostrum yield, the losses of $\mathrm{Ca}$ and $\mathrm{Mg}$ in colostrum were greater than those observed for cows fed $\mathrm{CH}$. Feeding the diet with negative DCAD reduced plasma concentrations of 25-hydroxyvitamin $\mathrm{D}_{3}$ in cows supplemented with $\mathrm{CH}$, suggesting that conversion of vitamin $\mathrm{D}_{3}$ into 25-hydroxyvitamin $\mathrm{D}_{3}$ might be influenced by acid-base status of dairy cows or the consequences of metabolic acidosis on PTH action and vitamin D metabolism. Treatments affected concentrations of serotonin and metabolites secreted by bone, suggesting some interplay between the dietary interventions imposed and regulatory hormones that influence mineral and energy metabolism.

\section{ACKNOWLEDGMENTS}

The authors thank Rafael S. Bisinotto, André L. G. Dias, José Freitas, Gabriel C. Gomes, Leandro F. Greco, Camilo Lopera, Kathryn Merriman, Kaitlin M. O'Connor, Adele Pietras, Guilherme C. S. Pontes, Eduardo S. Ribeiro, Rosiane Sales, Ricarda M. Santos, Johnathan Smith, Marcos Zenobi, and Matthew Wadford from the University of Florida (Gainesville) for their help with the conduct of the experiment; Sergei Sennikov at the University of Florida (Gainesville) for assistance with the analysis of samples; and Stephane Etheve from DSM Nutritional Products (Kaiseraugst, Switzerland) for conducting vitamin D analyses. Financial support for this experiment was provided by Arm \& Hammer Animal Nutrition (Princeton, NJ), DSM Nutritional Products (Kaiseraugst, Switzerland), and Dairy Australia (Southbank, Australia). 


\section{REFERENCES}

Baran, D. T., and M. L. Milne. 1986. 1,25-Dihydroxyvitamin D increases hepatocyte cytosolic calcium levels: A potential regulator of vitamin D-25 hydroxylase. J. Clin. Invest. 77:1622-1626.

Bikle, D. D. 2014. Vitamin D metabolism, mechanism of action, and clinical applications. Chem. Biol. 21:319-329.

Block, E. 1984. Manipulating dietary anions and cations for prepartum dairy cows to reduce incidence of milk fever. J. Dairy Sci. 67:2939-2948.

Box, G. E. P., and D. R. Cox. 1964. An analysis of transformations. J. R. Stat. Soc. B 26:211-252.

Brenza, H. L., and H. F. DeLuca. 2000. Regulation of 25-hydroxyvitamin D3 1alpha-hydroxylase gene expression by parathyroid hormone and 1,25-dihydroxyvitamin D3. Arch. Biochem. Biophys. 381:143-152.

Bronner, F. 1987. Intestinal calcium absorption: Mechanisms and applications. J. Nutr. 117:1347-1352.

Casas, E., R. J. Leach, T. A. Reinhardt, R. M. Thallman, J. D. Lippolis, G. L. Bennett, and L. A. Kuehn. 2013. A genomewide association study identified CYP2J2 as a gene controlling serum vitamin D status in beef cattle. J. Anim. Sci. 91:3549-3556.

Chabbi-Achengli, Y., A. E. Coudert, J. Callebert, V. Geoffroy, F. Côté, C. Collet, and M. C. de Vernejoul. 2012. Decreased osteoclastogenesis in serotonin deficient mice. Proc. Natl. Acad. Sci. USA 109:2567-2572.

Charbonneau, E., D. Pellerin, and G. Oetzel. 2006. Impact of lowering dietary cation-anion difference in nonlactating dairy cows: A metaanalysis. J. Dairy Sci. 89:537-548.

Corlett, S. C., M. S. Chaudhary, S. Tomlinson, and A. D. Care. 1987. The involvement of intracellular calcium ion concentration and calmodulin in the 25-hydroxylation of cholecalciferol in ovine and rat liver. Cell Calcium 8:247-258.

Curtis, C. R., H. Erb, C. Sniffen, R. Smith, P. Powers, M. Smith, M. White, R. Hillman, and E. Pearson. 1983. Association of parturient hypocalcemia with eight periparturient disorders in Holstein cows. J. Am. Vet. Med. Assoc. 183:559-561.

Dahlbäck, H., and K. Wikvall. 1987. 25-Hydroxylation of vitamin $\mathrm{D}_{3}$ in rat liver: roles of mitochondrial and microsomal cytochrome P-450. Biochem. Biophys. Res. Commun. 142:999-1005.

Ender, F., I. W. Dishington, and A. Helgebostad. 1971. Calcium balance studies in dairy cows under experimental induction or prevention of hypocalcaemia paresis puerperalis. Z. Tierphysiol. Tierernahr. Futtermittelkd. 28:233-256.

Fraser, D. R., and E. Kodicek. 1970. Unique biosynthesis by kidney of a biologically active vitamin D metabolite. Nature 228:764-766.

Fraser, D. R., and E. Kodicek. 1973. Regulation of 25-hydroxycholecalciferol-1-hydroxylase activity in kidney by parathyroid hormone. Nat. New Biol. 241:163-166.

Goff, J. P., A. Liesegang, and R. Horst. 2014. Diet-induced pseudohypoparathyroidism: A hypocalcemia and milk fever risk factor. J. Dairy Sci. 97:1520-1528.

Horst, R. L., J. Goff, and T. Reinhardt. 1994. Calcium and vitamin D metabolism in the dairy cow. J. Dairy Sci. 77:1936-1951.

Horst, R. L., J. P. Goff, and T. A. Reinhardt. 1990. Advancing age results in reduction of intestinal and bone 1,25-dihydroxyvitamin D receptor. Endocrinology 126:1053-1057.

Horst, R. L., E. Littledike, J. Riley, and J. Napoli. 1981. Quantitation of vitamin D and its metabolites and their plasma concentrations in five species of animals. Anal. Biochem. 116:189-203.

Horst, R. L., and T. A. Reinhardt. 1983. Vitamin D metabolism in ruminants and its relevance to the periparturient cow. J. Dairy Sci. 66:661-678.

Horst, R. L., T. A. Reinhardt, C. F. Ramberg, N. J. Koszewski, and J. L. Napoli. 1986. 24-Hydroxylation of 1,25-dihydroxyergocalciferol. An unambiguous deactivation process. J. Biol. Chem. 261:92509256.

House, W. A., and A. W. Bell. 1993. Mineral accretion in the fetus and adnexa during late gestation in Holstein cows. J. Dairy Sci. 76:2999-3010.
Jones, G. 2008. Pharmacokinetics of vitamin D toxicity. Am. J. Clin. Nutr. 88(Suppl.):582S-586S.

Jørgensen, E., and A. R. Pedersen. 1998. How to obtain those nasty standard errors from transformed data - and why they should not be used. Biometry Research Unit-Internal report 7. Danish Institute of Agricultural Sciences, Tjele, Denmark.

Kim, D., Y. Kawakami, N. Yamagishi, I. Abe, K. Furuhama, B. Devkota, N. Okura, S. Sato, and S. Ohashi. 2011. Response of plasma bone markers to a single intramuscular administration of calcitriol in dairy cows. Res. Vet. Sci. 90:124-126.

Laporta, J., K. P. Keil, C. M. Vezina, and L. L. Hernandez. 2014a. Peripheral serotonin regulates maternal calcium trafficking in mammary epithelial cells during lactation in mice. PLoS One 9:e110190.

Laporta, J., K. P. Keil, S. R. Weaver, C. M. Cronick, A. P. Prichard, T. D. Crenshaw, G. W. Heyne, C. M. Vezina, R. J. Lipinski, and L. L. Hernandez. 2014b. Serotonin regulates calcium homeostasis in lactation by epigenetic activation of hedgehog signaling. Mol. Endocrinol. 28:1866-1874.

Lean, I. J., P. J. DeGaris, P. Celi, D. M. McNeill, R. M. Rodney, and D. R. Fraser. 2014. Influencing the future: Interactions of skeleton, energy, protein and calcium during late gestation and early lactation. Anim. Prod. Sci. 54:1177-1189.

Lean, I. J., P. DeGaris, D. McNeil, and E. Block. 2006. Hypocalcemia in dairy cows: Meta-analysis and dietary cation anion difference theory revisited. J. Dairy Sci. 89:669-684.

Lee, N. K., H. Sowa, E. Hinoi, M. Ferron, J. D. Ahn, C. Confavreux, R. Dacquin, P. J. Mee, M. D. McKee, and D. Y. Jung. 2007. Endocrine regulation of energy metabolism by the skeleton. Cell 130:456-469.

Martinez, N., C. A. Risco, F. S. Lima, R. S. Bisinotto, L. F. Greco, E. S. Ribeiro, F. P. Maunsell, K. N. Galvão, and J. E. P. Santos. 2012. Evaluation of peripartal calcium status, energetic profile, and neutrophil function in dairy cows at low or high risk of developing uterine disease. J. Dairy Sci. 95:7158-7172.

Martinez, N., R. M. Rodney, E. Block, L. L. Hernandez, C. D. Nelson, I. J. Lean, and J. E. P. Santos. 2018a. Effects of prepartum dietary cation-anion difference and source of vitamin D in dairy cows: Lactation performance and energy metabolism. J. Dairy Sci. 101:2544-2562. https://doi.org/10.3168/jds.2017-13739.

Martinez, N., R. Rodney, E. Block, L. L. Fernandez, C. D. Nelson, I J. Lean, and J. E. P. Santos. 2018b. Effects of prepartum dietary cation-anion difference and source of vitamin $\mathrm{D}$ in dairy cows: Health and reproductive responses. J. Dairy Sci. 101:2563-2578. https://doi.org/10.3168/jds.2017-13740.

Martinez, N., L. D. Sinedino, R. S. Bisinotto, E. S. Ribeiro, G. C. Gomes, F. S. Lima, L. F. Greco, C. A. Risco, K. N. Galvão, D. Taylor-Rodriguez, J. P. Driver, W. W. Thatcher, and J. E. P. Santos. 2014. Effect of induced subclinical hypocalcemia on physiological responses and neutrophil function in dairy cows. J. Dairy Sci. 97:874-887.

McNamara, J. P. 1991. Regulation of adipose tissue metabolism in support of lactation. J. Dairy Sci. 74:706-719.

Naito, Y., N. Shindo, R. Sato, and D. Murakami. 1990. Plasma osteocalcin in preparturient and postparturient cows: Correlation with plasma 1, 25-dihydroxyvitamin D, calcium, and inorganic phosphorus. J. Dairy Sci. 73:3481-3484.

NRC. 2001. Nutrient Requirements of Dairy Cattle. 7th rev. ed. Natl. Acad. Press, Washington, DC.

Nelson, C. D., J. D. Lippolis, T. A. Reinhardt, R. E. Sacco, J. L. Powell, M. E. Drewnoski, M. O'Neil, D. C. Beitz, and W. P. Weiss 2016. Vitamin D status of dairy cattle: Outcomes of current practices in the dairy industry. J. Dairy Sci. 99:10150-10160.

Nelson, C. D., T. A. Reinhardt, J. D. Lippolis, R. E. Sacco, and B. J. Nonnecke. 2012. Vitamin D signaling in the bovine immune system: A model for understanding human vitamin D requirements. Nutrients 4:181-196.

Pike, J. W. 2011. Genome-wide principles of gene regulation by the vitamin D receptor and its activating ligand. Mol. Cell. Endocrinol. 347:3-10.

Poindexter, M. B. 2017. Effects of supplemental 25-hydroxyvitamin D3 on mineral concentrations and mastitis resistance in lactating 
dairy cows. MS thesis. Department of Animal Sciences, University of Florida.

Ponchon, G., A. L. Lennan, and H. F. DeLuca. 1969. "Activation" of vitamin D by the liver. J. Clin. Invest. 48:2032-2037.

Price, P. A., J. W. Poser, and N. Raman. 1976. Primary structure of the gammacarboxyglutamic acid-containing protein from bovine bone. Proc. Natl. Acad. Sci. USA 73:3374-3375.

Quinlan, K. P., and M. A. DeSesa. 1955. Spectrophotometric determination of phosphorus as molybdovanadophosphoric acid. Anal. Chem. 27:1626-1629.

Ramberg, C. F., G. Mayer, D. Kronfeld, J. Phang, and M. Berman. 1970. Calcium kinetics in cows during late pregnancy, parturition, and early lactation. Am. J. Physiol. 219:1166-1177.

Rodney, R., P. Celi, J. McGrath, H. Golder, S. Anderson, D. McNeill, D. Fraser, and I. Lean. 2018. Metabolic and production responses to calcidiol treatment in mid-lactation dairy cows. Anim. Prod. Sci. 58. In press. (accepted).

Sato, R., K. Onda, H. Ochiai, T. Iriki, Y. Yamazaki, and Y. Wada. 2011. Serum osteocalcin in dairy cows: Age-related changes and periparturient variation. Res. Vet. Sci. 91:196-198.

Taylor, M. S., K. Knowlton, M. McGilliard, W. Seymour, and J. Herbein. 2008. Blood mineral, hormone, and osteocalcin responses of multiparous Jersey cows to an oral dose of 25-hydroxyvitamin $\mathrm{D}_{3}$ or vitamin $\mathrm{D}_{3}$ before parturition. J. Dairy Sci. 91:2408-2416.

Valadares, R. F., G. Broderick, S. Valadares Filho, and M. Clayton. 1999. Effect of replacing alfalfa silage with high moisture corn on ruminal protein synthesis estimated from excretion of total purine derivatives. J. Dairy Sci. 82:2686-2696.

Vieira-Neto, A., I. R. P. Lima, F. Lopes Jr., C. Lopera, R. Zimpel, L. D. P. Sinedino, K. C. Jeong, K. Galvão, W. W. Thatcher, C. D. Nelson, and J. E. P. Santos. 2017. Use of calcitriol to maintain postpartum blood calcium and improve immune function in dairy cows. J. Dairy Sci. 100:5805-5823.

Visek, W. J., R. A. Monroe, E. W. Swanson, and C. L. Comar. 1953 Calcium metabolism in dairy cows as studied with $\mathrm{Ca}^{45}$. J. Dairy Sci. 36:373-383.

Wallis, G. C., G. H. Kennedy, and R. H. Fishman. 1958. The vitamin D content of roughages. J. Anim. Sci. 17:410-415.

Weiss, W. P., E. Azem, W. Steinberg, and T. A. Reinhardt. 2015. Effect of feeding 25-hydroxyvitamin $\mathrm{D}_{3}$ with a negative cation-anion difference diet on calcium and vitamin $\mathrm{D}$ status of periparturient cows and their calves. J. Dairy Sci. 98:5588-5600.

Wilkens, M. R., G. Breves, and B. Schröder. 2014. A goat is not a sheep: Physiological similarities and differences observed in two ruminant species facing a challenge of calcium homeostatic mechanisms. Anim. Prod. Sci. 54:1507-1511.

Wilkens, M. R., I. Oberheide, B. Schröder, E. Azem, W. Steinberg, and G. Breves. 2012. Influence of the combination of 25-hydroxyvitamin $\mathrm{D}_{3}$ and a diet negative in cation-anion difference on peripartal calcium homeostasis of dairy cows. J. Dairy Sci. 95:151-164.

Wolf, G. 2008. Energy regulation by the skeleton. Nutr. Rev. 66:229233 